\title{
Geografia do comércio de commodities, dinâmicas espaciais da logística de transportes e dos fluxos de exportações do setor de soja no Brasil
}

\author{
The geography of commodities trade, transport logistics space \\ dynamics and flow of soybean exports in Brazil
}

\author{
Luiz Andrei Gonçalves Pereira ', Igor José Ferreira dos Santos ", William \\ Rodrigues Ferreira "'I
}

\begin{abstract}
RESUMO
Nas atividades agrocomerciais, as exportações de commodities agrícolas, incluindo a soja e seus derivados, abastecem os mercados globais no atendimento das demandas do setor agroindustrial, agroalimentício e agroenergético, por isso a logística de transportes interconecta fisicamente as áreas produtoras e os mercados consumidores. O objetivo deste artigo é analisar a espacialização da logística de transportes que articula o escoamento das exportações do setor de soja, em uma configuração territorial que engloba a roteirização entre o Brasil e os mercados internacionais, no período de 1997 a 2016. Adotou-se como metodologia a revisão de literatura, coleta e análise de dados secundários, disponibilizados pelas instituições brasileiras e pelos institutos estrangeiros. Os fluxos das exportações do setor de soja e de seus derivados concentraram-se nos mercados asiáticos e europeus, que são interligados pela matriz de transporte nacional rodoviária, ferroviária e hidroviária, com concentração dos produtos nos recintos alfandegados portuários e no transporte marítimo em percursos internacionais.
\end{abstract}

Palavras-chave: Geografia; Commodities agrícolas; Logística de transportes; Exportações; Setor de soja

\section{ABSTRACT}

In agro-commercial activities, agricultural exports commodities, including soybeans and their byproducts, supply global markets to meet demands of the agribusiness, agri-food and agroenergy sectors, so transportation logistics physically interconnects the producing areas and consumer markets. This article aims to analyze the spatialization of transport logistics that articulates soybean flow exports, in a territorial configuration that encompasses the routing between Brazil and international markets, from 1997 to 2016. It was adopted as methodology, literature review, collection and analysis of secondary data, made available by Brazilian institutions and foreign institutes. Soybean and soy products export flows sector were concentrated in the Asian and European markets, which are interconnected by the

'Professor do Departamento de Geociências e do Programa de Pós-Graduação em Geografia (UNIMONTES). E-mail: luizandreigoncalves@yahoo.com.br ORCID: https://orcid.org/0000-0002-7857-6611

"Graduado em Geografia (UNIMONTES) E-mail: igorjose563@yahoo.com.br ORCID: https://orcid.org/0000-0002-2960-2393

III Professor do Instituto de Geografia e do Programa de Pós-Graduação em Geografia (UFU). E-mail: wferreira@ufu.br ORCID: https://orcid.org/0000-0002-0312-1700 
2 | Geografia do comércio de commodities, dinâmicas espaciais da logística de transportes e dos fluxos de exportações do setor de soja no Brasil

national road, rail and waterway transport matrix, with concentration of products in port customs and maritime transport in international routes.

Keyword: Geography; Agricultural commodities; Transport logistic; Exports; Soybean industry

\section{INTRODUÇÃO}

Nas atividades agrocomerciais, as exportações de commodities agrícolas abastecem os mercados globais, atendendo as demandas do setor agroindustrial, agroalimentício e agroenergético, a logística de transportes interconecta fisicamente as áreas produtoras e os mercados consumidores. Nos mercados internacionais, os agentes econômicos brasileiros e estrangeiros destacam-se na produção e exportação de produtos agroindustriais, dentre os quais estão inseridos a soja in natura e seus derivados, constituindo assim o setor de soja.

No segmento da sojicultura, a logística de transportes configura-se como um mecanismo importante no escoamento dos fluxos materiais de soja e seus derivados, com uma estrutura espacial que incorpora as fazendas, os armazéns, os recintos alfandegados e os mercados globais. As interações espaciais sucedem a partir da infraestrutura e dos serviços de transporte e comunicação, que interconectam os agentes econômicos em diversos mercados no espaço geográfico mundial. A dinâmica socioeconômica da sojicultura no Brasil tem demandado estudos, buscando explicação e/ou compreensão das formas de organização das estruturas produtivas e de comercialização no mercado internacional. A concretização de vendas exige planejamento, gerenciamento e controle das atividades logísticas - incluindo os transportes - para que as mercadorias possam ser entregues nos destinatários de forma econômica (baixo custo), rápida e segura em qualquer lugar, território e/ou região.

Adotando o contexto global da produção e do comércio de soja e derivados, este estudo tem como base a seguinte problematização: de que forma os agentes econômicos (pessoas, empresas e Estados) organizam a produção, a 
comercialização e a circulação do setor de sojicultura nas interações socioespaciais entre o Brasil e os mercados globais? O objetivo deste artigo é analisar a espacialização da logística de transportes que articula o escoamento das exportações do setor de soja, em uma configuração territorial que engloba a roteirização entre o Brasil e os mercados internacionais, no período compreendido entre 1997 a 2016.

Os recursos metodológicos utilizados no processo de elaboração deste artigo consistiram em revisão de literatura, visando garantir uma discussão teórica-conceitual dos temas relacionados à logística de transportes, às estruturas de produção e às dinâmicas de comercialização de soja e seus derivados nos mercados globais. Os dados coletados, organizados e analisados foram disponibilizados pelo sistema virtual do ALICEWEB2, vinculado ao Ministério da Indústria, Comércio Exterior e Serviços - MDIC, pelo Ministério dos Transportes, Portos e Aviação Civil, ambos brasileiros, também pelos organismos internacionais, destacando-se a Organização das Nações Unidas para a Alimentação e a Agricultura - FAO, o International Trade Centre - ITC/Trade Map e a United States Department of Agriculture - USDA.

Com base nas informações coletadas, os produtos do setor de soja foram organizados pelos códigos do Sistema Harmonizado - SH e/ou Nomenclatura Comum do Mercosul - NCM, seguindo uma padronização internacional, utilizada na identificação de produtos exportados e importados no mercado mundial. Considerando as informações dos produtos exportados, quantificou-se os fluxos por recintos alfandegados (portos, aeroportos e pontos de fronteiras), pelos meios de transportes (nacionais e internacionais) e pelos mercados globais de destino, que foram agrupados em blocos econômicos e/ou países, visualizados em ilustrações formuladas com os auxílios dos softwares ARCGIS (versão 10.2) e Excel (versão 2010). 


\subsection{A Geografia da comercialização de commodities agrícolas: a soja e seus derivados}

As atividades comerciais ligadas à agricultura e à (agro)indústria demandam estudos de pesquisadores geógrafos e de áreas afins que fomentem as discussões relativas às interações espaciais entre os fluxos de bens materiais (mercadorias) e de bens imateriais (informações e serviços). Para Negut (2011), os geógrafos têm uma estreita relação para lidar com o comércio, desde a época, que os antigos viajantes levavam as mercadorias com possíveis potencialidades de ser negociadas em diversos espaços que iam sendo ocupados. Segundo Trigal et al. (2015), o comércio é uma atividade econômica articulada por interações de compra e venda de bens e de serviços por agentes econômicos - as empresas e/ou os consumidores - que operacionalizam os canais comerciais por meio de um sistema de distribuição, sustentado pelos serviços das atividades logísticas de armazenagem e de transportes, incluindo também as transações financeiras necessárias para promover a circulação de bens e serviços nas articulações socioespaciais entre os produtores, os distribuidores e os consumidores finais.

No entender de Rodrigues, Comtois e Slack (2013), o comércio é caracterizado pelos meios de trocas que envolvem as transações e os fluxos associados de capital, de informação, de matérias-primas, de peças e/ou de produtos acabados em uma lógica espacial, que envolve a origem e o destino dos fluxos. Desta forma, Rossi-Hansberg (2005) destaca que o comércio pode ser definido como uma atividade socioeconômica essencialmente espacial por permitir a distribuição e os padrões socioespaciais dos fluxos intranacionais e internacionais de bens e serviços comercializáveis.

Ao discutir as dinâmicas políticas, econômicas, sociais e culturais na perspectiva do comércio global, Grant (2000) ressalta que a teoria das vantagens comparativas foi utilizada para a compreensão dos padrões e da especialização do comércio que exploram ao máximo as diferenças e as conexões dos lugares, nas várias escalas geográficas, em um processo de desenvolvimento econômico pautado nos princípios do livre comércio. Essa teoria apresenta limitações para explicar o comércio global contemporâneo, pois existem 
novas dimensões voltadas para a contabilização e para a espacialização dos fluxos comerciais. Destacando-se a complexidade da composição de setores e de tipos de comércio na esfera global; as barreiras comerciais (tarifárias e não tarifárias), e as interrelações nos papéis de governos e de empresas na organização do comércio.

As orientações do comércio internacional são distintas no complexo processo de fragmentação da produção que molda as novas dinâmicas geográficas das mercadorias, através de fluxos de produtos primários e de produtos (semi)acabados entreindústria e intraindústria, de alta tecnologia e de comércio eletrônico. As empresas ampliaram as suas relações comerciais por meio de alianças estratégicas e de contratos na combinação de diferentes tipos de fluxos em operações de mercados na economia global (GRANT, 2000). Ao desenvolver a discussão dos negócios na ciência Geográfica, Mcconnell e Erikson (1986) apontaram que as mudanças nos deslocamentos do comércio e dos investimentos internacionais criaram um capital hipermóvel e um poder econômico concentrado, condicionando o sucesso da corporação multinacional à comercialização de informações, de dados, de tecnologias e de experiências gerenciais, não concentrando as suas atividades exclusivamente em produtos manufaturados.

A internacionalização das operações de empresas ampliou as vendas de produtos e de serviços nos mercados globais. Porém, diante das restrições impostas ao comércio, as empresas precisam de serviços especializados para superação de problemas relacionados às moedas, às taxas de juros, à inflação e às políticas fiscais. Além disso, os governos nacionais criaram ações políticas e institucionais que regulam os negócios dentro de seus territórios, destancado-se a implementação de barreiras comerciais, pricipalmente para as importações de produtos (MCCONNELL; ERICKSON, 1986). Para Hughes (2006), as barreiras comerciais criaram e/ou criam obstáculos para a ampliação do comércio na esfera global.

As intervenções políticas são visíveis nas estruturas de transação do comércio internacional, por meio de ações estatais que implementaram as regulações e as normatizações dos mercados nacionais, se por um lado, foi uma forma de garantir a segurança dos produtos a serem consumidos, em termos de qualidade, conforme os quesitos das normas ambientais, sanitárias e trabalhistas vigentes através de acordos internacionais, por outro, criaram empecilhos para o 
comércio global, ao incorporar uma multiplicidade de códigos, regras (normas) e certificações, pensando no protecionismo do mercado nacional e coibindo as importações, principalmente daqueles setores mais tradicionais da economia, como é o caso da agricultura, da indústria têxtil e da siderurgia, que são protegidos da concorrência estrangeira pela aplicação de barreiras tarifárias e não tarifárias (HUGHES, 2006). É importante lembrar que o Estado tem o papel institucional de impor as barreiras e de dinamizar o comércio pela negociação de acordos com os seus parceiros comerciais.

O comércio internacional de produtos agrícolas tem vivenciado a imposição de barreiras comerciais. Segundo Medeiros (2014), nos Estados Unidos e na União Europeia, os setores agrícolas são protegidos por meio de estratégias das políticas nacionais de implantação de barreiras (tarifárias e não tarifárias) para as importações e também de implementação de subsídios para as exportações, visando à competitividade no mercado global. Em decorrência do aumento da produção e das exportações de produtos agroalimentares nos países periféricos, os produtores norte-americanos e europeus têm pressionado o seus governos a protegê-los, criando um ambiente de concorrência desleal, onde o protecionismo por meio de barreiras alfandegárias e de subsídios, tornou-se foco de conflito diplomático no cenário econômico internacional. As ações desenvolvidas pela Organização Mundial do Comércio - OMC, principalmente através de rodadas de negociações, buscam resolver e/ou minimizar, no campo geopolítico de produtos agroalimentares, os problemas comerciais ligados ao protecionismo.

Apesar dos obstáculos diplomáticos, presentes no comércio global de commodities alimentares, através da utilização de barreiras alfandegárias e de subsídios, é notório o crescimento do setor agroindustrial. Para Lima (2018), a expansão do agronegócio ocorreu por causa da interação entre as atividades produtivas agrícolas, as indústrias de insumos, as indústrias de processamento, as inovações tecnológicas, as atividades comerciais, os serviços financeiros e os 
serviços de distribuição, integrando e coordenando o complexo sistema agroindustrial.

A financeirização da agricultura provocou mudanças significativas nas formas de investimentos e de comercialização de commodities agrícolas nos mercados globais. A dinâmica do comércio de produtos agroalimentares nos mercados futuros foi determinante para a política de preços, na medida em que sua influência no sistema financeiro tem provocado especulação, que aumentou os preços das commodities negociadas, utilizadas na produção de biocombustíveis e no consumo de alimentos. As regulações do preço de produtos agroalimentares, passam pelas expectativas de investimentos em bolsas de mercadorias e de contratos futuros, que estabelecem os preços de comercialização em período anterior ao plantio e a colheita da safra agrícola (MEDEIROS, 2014). Além dos fatores citados, também existem riscos responsáveis pela volatilidade que levam a alta ou baixa nos preços da produção agroalimentar nos mercados globais.

As variações nos preços de comercialização de produtos agroindustriais, nos mercados físicos e/ou bolsa de mercadorias e de mercados futuros, são influenciadas pelas formas de integração das redes produtivas com os mercados internacionais, pelas epidemias, pelas variações climáticas, pela diminuição de estoques, pela redução da produção, pela especulação financeira, pela escassez de créditos para investimento na produção, pelo aumento dos preços dos insumos oriundos das indústrias petroquímicas, pelas demandas do segmento de biocombustíveis, dentre outros fatores (WAQUIL; MIELE; SCHULTZ, 2010; BINI, CANEVER, DENARDIM, 2015). A instabilidade nos preços das commodities agrícolas, principalmente no momento de declínio nos preços, segundo Waquil; Miele; Schultz (2010), tem relação com o excesso de oferta de grãos por causa da desregulação, a ausência e/ou redução de barreiras para a entrada de produtos originários dos países periféricos e a centralização de demandas em um pequeno número de empresas que monopolizam os mercados. As empresas que atuam no segmento alimentar - trading companies - e as redes de supermercados 
monopolizam e controlam a aquisição, o processamento e a comercialização de produtos agroindustriais, dificultando a entrada de novas empresas nos mercados.

Ao discutir a mundialização do capitalismo monopolista do setor agroalimentar, Oliveira (2016) nota que os mercados de produtos agroalimentares se organizam em uma tríade (Europa, Estados Unidos e Japão) que controlam: 1) a produção de commoditie agrícola torna-se comercializada e consumida em qualquer lugar do mundo, principalmente pelas pessoas que tem poder aquisitivo. 2) A regulação dos preços das commodities agrícolas pelas bolsas de mercados e mercados futuros, sendo referência a Chicago Mercantile Exchange - CME, Bolsa de Chicago, na formulação de políticas de preços de commodities que são comercializadas nos mercados globais. 3) A rede de matrizes e de filiais de empresas multinacionais que atuam no controle da produção de matéria-prima, do processamento industrial, do comércio e do financiamento das cadeias produtivas dos setores agroalimentares, destacando-se as companhias Archer Daniels Midland - ADM, Bunge, Cargill e Louis Dreyfus.

Nos mercados de grãos in natura (não processados) e de seus derivados (produtos processados), as empresas multinacionais desenvolvem estratégias que influenciam as políticas e as atividades comerciais no direcionamento dos volumes, dos preços e dos fluxos de produtos agroalimentares no cenário global (SCOPPOLA, 1993). Os grãos podem ser processados na integração dos mercados e direcionados pelos investimentos públicos e privados na produção e no consumo de carnes pela população, expandindo assim, o setor de ração para a criação de animais. Os setores agroalimentares, constituídos de grãos, foram puxados internacionalmente em um primeiro momento pelo trigo, e em um segundo momento pela produção de milho e de soja. Isso demanda investimentos nas formas de processamento, de conservação e de transportes de alimentos no atendimento das demandas de compradores e consumidores localizados em regiões distantes no cenário internacional (LIMA, 2018). Dentre as commodities 
agrícolas comercializadas, o setor de grãos é constituído por arroz, trigo, cevada, milho, sorgo, soja, dentre outros.

$\mathrm{Na}$ estrutura do comércio internacional da soja e seus derivados, Bader (1981) reforça que a soja passou a ser utilizada em várias partes do mundo no momento em que é incorporada na estrutura de nutrição mundial, através de demandas por proteínas e óleos vegetais. Na política de comercialização, os mercados da soja em grãos, de farelo de soja e de óleo de soja incorporam os intercâmbios, as armazenagens e os transportes entre as áreas produtoras locais, as plantas de processamento e canais de exportações. Na dinâmica econômica, o plantio de soja tem puxado os mercados auxiliares do comércio de bens e serviços, destacando-se os setores de maquinarias, de sementes, de herbicidas, de inseticidas, de finanças, de combustíveis, de armazenamentos e de transportes na integração de cadeias produtivas e no atendimento de demandas dos mercados de soja.

No mercado de soja e derivados, as corporações multinacionais que atuam no segmento do agronegócio, denominadas de trading companies, segundo Medeiros (2014) e Lima (2018), são empresas especializadas na comercialização, no processamento e na distribuição de produtos e de serviços nos mercados internacionais. Companhias tais como a ADM, Bunge, Cargill, Louis Dreyfus, Noble Group, Wilmar, Vitol, Cofco, dentre outras, são especializadas na articulação do sistema financeiro para estimular as linhas de financiamento e o gerenciamento de riscos nos negócios agrícolas. Na otimização da produção e do processamento de commodities agrícolas, a infraestrutura e os serviços logísticos tem o papel de promover a circulação dos produtos nos mercados (GEMAN, 2015). Para os agentes econômicos, as ofertas e demandas por serviços logísticos são imprescindíveis para as articulações socioespaciais do comércio global de soja e derivados, inclusive para a economia brasileira. Assunto este, discutido na seção seguinte. 


\subsection{Logística de transportes em atividades agroindustriais, organização da produção e comercialização do setor de soja no território brasileiro}

Nas dinâmicas socioeconômicas e nas interações socioespaciais dos segmentos de commodities agrícolas, a infraestrutura e os serviços logísticos de transportes incluindo os transportes, o sistema de armazenagem (galpões e silos) e os serviços de transbordo - assumem papel relevante na operacionalização dos fluxos das exportações de soja em grão (in natura) e de seus derivados (Farelo de soja, óleo de soja, farinha de soja, etc.). Neste contexto, no território brasileiro, a expansão da soja, das unidades processadoras (agroindústria), dos locais de armazenagens, da infraestrutura e dos serviços de logística buscou atender às demandas dos mercados consumidores nacionais e internacionais.

Ao considerar as atividades socioeconômicas, incluindo o setor do agronegócio, as empresas sistematizam a infraestrutura e os serviços logísticos com foco na integração de cadeias produtivas e de consumo por meio das interações espaciais dos fluxos de mercadorias e serviços. Conforme lembra Ballou (2006), as transformações ocorridas na logística contribuíram com para o rompimento das barreiras geográficas, ampliando as relações por meio de ocupações territoriais, da expansão das atividades comerciais e produtivas. O estabelecimento de inter-relações econômicas, sociais e culturais pelos agentes econômicos contribuiu para o crescimento do comércio, gerando as demandas pelos serviços de transportes, de armazenagem e de carga e descarga de mercadorias nos mercados (DAVID; STEWART, 2010).

O processo de sistematização do conhecimento acerca da logística desenvolveuse no campo militar, na medida em que foram aplicadas as técnicas táticas e estratégicas no planejamento, na gestão e no controle das movimentações de tropas militares, de equipamentos e materiais de combate, de mantimentos e de serviços médicos, nos períodos anteriores, durante e posteriores a guerra. No Pós Segunda 
Guerra Mundial, a logística moderna, a princípio desenvolvida e adotada pelos militares, foi também incorporada aos negócios do setor empresarial. As empresas adotaram a logística em suas atividades, pensando na competitividade dos mercados, por meio da aplicação de serviços táticos e estratégicos no planejamento, no gerenciamento e no controle da organização e das operações dos fluxos de matériasprimas, de produtos semiacabados e de produtos acabados, para atender às demandas das estruturas produtivas, dos distribuidores (atacadistas e varejistas) e dos consumidores. Incorporando os serviços do pós-consumo, que são os fluxos reversos nos mercados nacionais e globais (NOVAES, 2001; BALLOU, 2006; SILVEIRA, 2011; MONIÉ, 2011, PEREIRA, 2015). A logística é composta por uma gama de serviços complexos, contratados e empregados pelos agentes econômicos, na movimentação de mercadorias, no abastecimento das cadeias produtivas e no atendimento às demandas dos mercados consumidores.

Os serviços logísticos são preciosos na dinâmica das interações socioespaciais da circulação de bens nos mercados. De acordo com Ballou (1993), as atividades ligadas aos transportes, ao processamento de pedidos e à manutenção de estoques são centrais na logística, pois elas demandam recursos financeiros de custeio, coordenam e controlam a qualidade e o prazo de execução de tarefas no processo de operacionalização dos fluxos. Dentre as atividades core da logística, os transportes apresentam maior visibilidade e representam cerca de dois terços dos custos logísticos na movimentação de mercadorias. Considerando o papel dos serviços de transportes na dinâmica dos fluxos de bens, Pereira e Ferreira (2016, p. 71) usaram a conceituação da logística de transportes como:

Um segmento da logística responsável pelo planejamento, pelo gerenciamento e pelo controle dos serviços que auxiliam na tomada de decisão para a escolha do modal de transporte ou dos modais de transportes mais adequados para se operacionalizar o sistema de fluxos de mercadorias e de pessoas, no espaço geográfico local, regional, nacional e internacional, de forma rápida, eficiente, confiável, segura e, 
preferivelmente, de baixo custo. A operacionalização da logística de transportes depende da infraestrutura, dos terminais, dos fluxos de informações e dos serviços logísticos para se viabilizar a articulação espacial entre os fornecedores, os produtores, os prestadores de serviços, os comerciantes e os consumidores [...] a logística de transportes é uma atividade muito importante no processo de efetivação das trocas comerciais de bens e de serviços.

Na cadeia logística das commodities agrícolas, German (2015), nota que o gerenciamento dos transportes tem demandado um grande suporte na infraestrutura e nos serviços realizados por caminhões, trens, embarcações, silos de armazenagem, processadores e elevadores de grãos, na movimentação de matérias-primas e de mercadorias aptas a serem comercializadas. Além disso, existe ainda a prestação de serviços na gestão dos riscos dos preços, do custeio das taxas de envios, dos combustíveis, das transações financeiras e dos seguros de transportes. Essa estrutura de serviços torna-se relevante na expansão e na organização da produção do agronegócio.

No território brasileiro, Caixeta Filho (2010) alega que a economia agrícola agroindustrial despertou interesse pelas demandas de investimentos em políticas públicas de transportes e de comunicação para promover a organização espacial das atividades produtivas, uma vez que as empresas passaram a ocupar novas áreas e a aplicar o uso de técnicas modernas de produção, com o intuito de produzir matérias-primas, que podem ser armazenadas ou comercializadas para indústrias processadoras, localizadas nas proximidades ou distantes das áreas produtivas, visando à redução dos custos de transportes. A logística é incorporada na dinâmica da produção e da circulação, de forma estratégica para assegurar a competividade de empresas nos mercados nacionais e internacionais, através da otimização e adequações na movimentação espacial dos produtos agroalimentares. Nas cadeias do agrocomércio, a perecibilidade dos produtos no pós-colheita demanda o planejamento das atividades logísticas de transportes e 
de armazenagem, buscando a minimização de custos com perdas, a eficiência dos serviços prestados e a maximização dos lucros.

As atividades pós-colheita estão interligadas pelas operações de préprocessamento, de processamento, de transportes, de armazenamentos, de embalagens e de comercialização. Na movimentação de produtos agroalimentares existe a necessidade de racionalizar a utilização dos meios de transportes ferroviários, rodoviários e hidroviários para a circulação de produtos de baixo valor agregado e alto peso/volume, destacando-se nesse segmento a soja e o milho. Nessas categorias de produtos, os custos logísticos de transportes são mais significativos e impactam o valor final do produto nos mercados, principalmente com o custeio dos fretes (CAIXETA FILHO, 2001; CAIXETA FILHO, 2010). Castillo (2005) considera que a circulação de produtos, que são consumidos em áreas distantes das regiões produtivas, tem demandado a maximização do uso de infraestrutura de transportes e de armazenamento para que os custos logísticos não sobrecarreguem os preços dos produtos movimentados, uma vez que a maioria dos graneis agrícolas é de baixo valor agregado e acabam pressionando os custos dos transportes. Por isso, existe a necessidade de uma escolha criteriosa dos meios de transportes a serem utilizados, de modo a contribuir com uma fluidez mais eficiente dos produtos para o mercado interno e externo, com mais velocidade, qualidade e baixo custo.

As políticas de produção e de exportações do setor agroindustrial, incluindo a soja e seus derivados, têm demando infraestrutura logística de transportes, visando o escoamento dos produtos até as unidades armazenadoras e/ou até os mercados consumidores nacionais e internacionais. Nos arranjos espaciais, segundo Caixeta Filho (2001), os empreendimentos agrícolas de monoculturas do complexo da soja têm cobrado medidas mais concretas voltadas à logística no tocante aos projetos de melhorias na infraestrutura para o escoamento de soja e 
derivados em áreas tradicionais e nas novas fronteiras agrícolas. A matriz de transportes tornou-se uma preocupação frequente das empresas agrícolas nos escoamentos de seus produtos para os mercados, demandando interconexões dos modais hidroviários, ferroviários, rodoviários e marítimos. Entretanto, a economia brasileira tornou-se dependente do modal rodoviário, enquanto as hidrovias e ferrovias são pouco utilizadas (CAIXETA FILHO, 2001; CASTILLO, 2005).

Na política para transportes do território brasileiro, a infraestrutura de transportes foi planejada e operacionalizada por empresas estatais, no período que abrangeu de meados da década de 1950 até 1990. A crise econômica enfrentada pelo Brasil a partir do final dos anos 1970 restringiu os investimentos na infraestrutura de transportes, o que acarretou seu sucateamento. Na visão neoliberal, a saída para a reestruturação da infraestrutura brasileira dependia da participação do capital privado. Após os anos de 1990, o Estado, por meio de regime de concessão, repassou a infraestrutura de transportes para as empresas privadas investirem e operacionalizar, principalmente nas áreas de grande concentração de capital. Neste contexto, as ações do Estado e da iniciativa privada têm priorizado o transporte rodoviário para a circulação de cargas e de passageiros em detrimentos aos outros modos de transportes (CAIXETA FILHO, 2001, CASTILLO, 2005; PEREIRA, 2010). A infraestrutura e os serviços de transportes são utilizados para o escoamento da produção nas conexões com os mercados.

A distribuição espacial da logística de transportes: rodoviária, ferroviária e hidroviária no território brasileiro, incluindo os terminais intermodais e os recintos alfandegados, voltada para o setor de soja e derivados, que atende as demandas de indústrias processadoras localizadas no mercado nacional e dos setores exportadores, que se concentram em áreas agrícolas tradicionais (Sul e Sudeste) e em novas áreas de fronteiras agrícolas, principalmente nos cerrados do CentroOeste, Nordeste e Sudeste do Brasil. Desta forma, os empresários usaram o 
transporte rodoviário, ferroviário e hidroviário no escoamento dos produtos de soja e derivados direcionados aos mercados internacionais.

Considerando-se a infraestrutura da logística de transportes brasileira, as principais rotas para o escoamento da soja e derivados são: 1) Corredor de exportação Norte e Nordeste - transporte rodoviário pela BR 163; BR 158; BR 135; BR 364; BR 135 e BR 242. O transporte ferroviário pela Ferrovia Norte-Sul e Estrada de Ferro Carajás e o Transporte hidroviário pelas hidrovias do rio Madeira, Rio Amazonas e rio Tapajós. 2) Corredor de exportação Sudeste e Sul - transporte rodoviário pelas BR 158; BR 163; BR 262; BR 364; BR 365; BR 040; BR 050; BR 374; BR 376; BR 277; BR 392; dentre outras. O transporte ferroviário pela ferrovia América Latina Logística - ALL (malha sul); América Latina Logística - ALL (malha Norte e Paulista) e Valor da Logística Integrada - VLI. E as hidrovias do rio TietêParaná, Hidrovia do Paraguai e Hidrovia da Lagoa dos Patos (MTPA, 2018a).

A demanda pelos meios de transportes aumenta no período do pico das safras, geralmente nos meses de fevereiro, março, abril e maio, o que consequentemente acaba elevando os custos dos fretes. De acordo com Castillo (2005), a movimentação dos produtos necessita definir critérios na escolha do modo de transporte para diminuir a sobrecarga dos custos, uma vez que os produtos agrícolas apresentam baixo valor agregado e grande volume, pressionando os custos dos transportes. Para Caixeta Filho et al. (2001), os custos dos fretes aumentam em razão da frota de caminhões não ser suficiente para escoar a produção de commodities, incluindo a soja, levando as empresas a buscar novas alternativas de escoamento, dentre elas, destaca-se o transporte pela ferrovia FERRONORTE e pela hidrovia do Rio Madeira. O Mapa 01 mostra a distribuição espacial da infraestrutura e dos serviços de transportes no território brasileiro. 
16 | Geografia do comércio de commodities, dinâmicas espaciais da logística de transportes e dos fluxos de exportações do setor de soja no Brasil

Mapa 01 - Representação espacial da infraestrutura no Brasil: logística de transportes e principais rotas de escoamento de soja e derivados

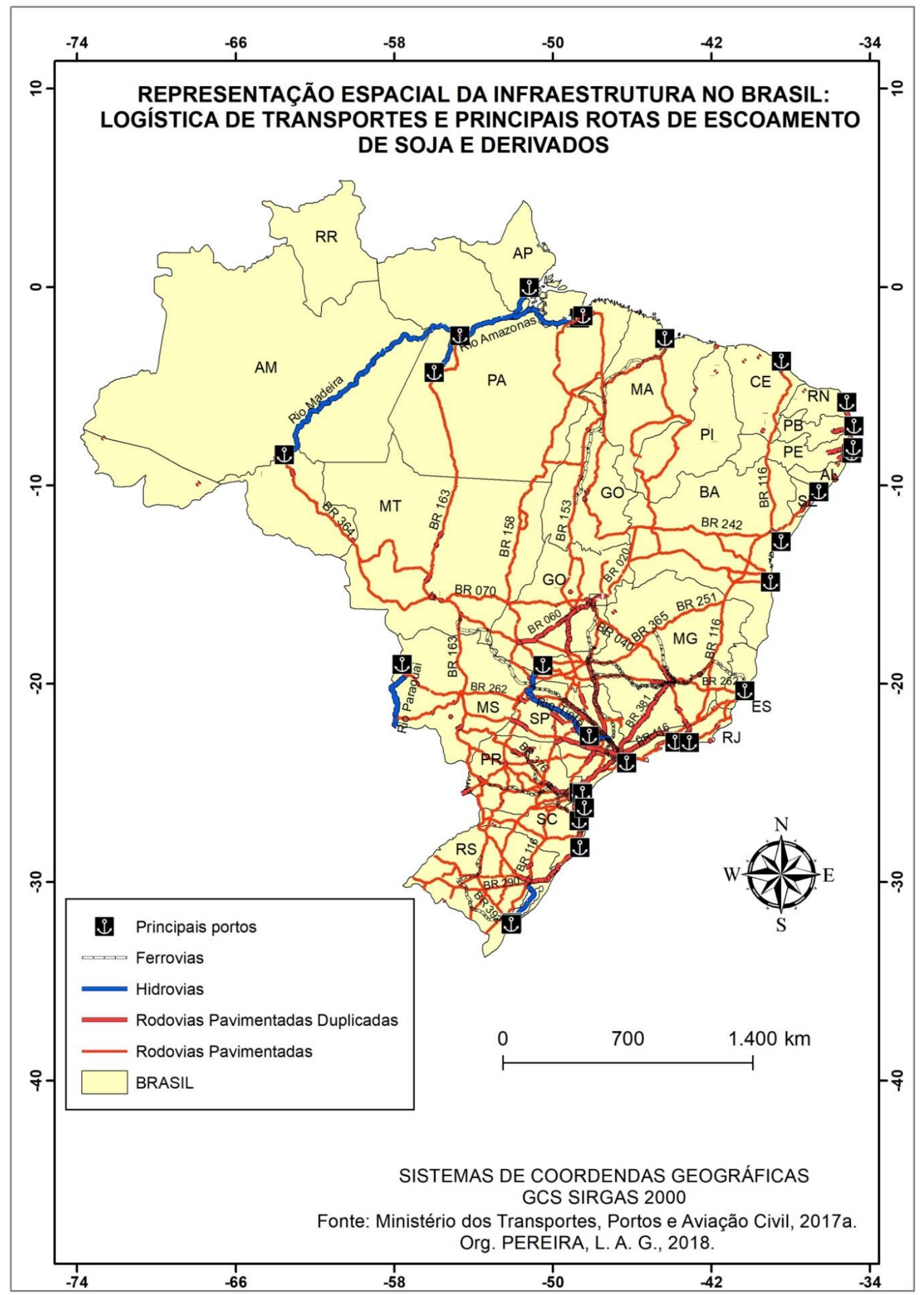

Fonte: Ministério dos Transportes, Portos e Aviação Civil - MTPA, 2017a. Org. PEREIRA, L. A. G., 2018 
No aumento dos custos dos fretes e na queda dos preços de produtos agrícolas, por causa do excesso de produto ofertado no mercado, uma medida a ser adotada poderia ser a armazenagem da produção, o que reduziria a demanda pelos transportes, baixando os custos dos fretes, podendo ainda esperar melhora de preço no período da entressafra (MARTINS et al., 2005). Considerando a qualidade dos produtos nos mercados, segundo Pontes, Carmo e Porto (2009), a armazenagem é um processo desenvolvido para evitar as perdas, garantir a conservação, retirar as impurezas e diminuir a unidade dos produtos agrícolas na cadeia de comercialização e de transportes. Conforme Frederico (2010), a armazenagem tornou-se uma estratégia desenvolvida pelos agentes econômicos do setor agroalimentar para o controle dos estoques durante o processo de produção, de processamento e de distribuição das mercadorias pelos produtores, atacadistas e varejistas no mercado nacional e internacional. Na armazenagem busca-se regular os estoques dos produtos na distribuição durante o período de safras e de entressafras, buscando equilibrar os preços dos produtos agroalimentares.

No contexto da modernização da agricultura brasileira, Frederico (2010) aponta que a estratégia de armazenagem de grãos do agronegócio ocorreu em dois momentos, no primeiro momento, que vai de meados da década de 1960 até a década de 1980, no qual se tem uma maior participação estatal na construção e na operacionalização da rede de armazéns. Enquanto no segundo momento, o Estado retirou-se da intervenção, concedendo ao setor privado uma participação mais efetiva na operacionalização da rede de armazéns (silos), na medida em que as tradings companies e os especuladores financeiros adotaram as estratégias de mercado para lucrar no mercado físico e financeiro do segmento de commodities 
agrícolas. Na configuração territorial da rede de armazenagem no território brasileiro, o Mapa 02 demonstra a localização dos armazéns e dos silos no Brasil que são utilizados para escoamento e/ou estocagem de grãos, dentre eles, destaca-se a soja.

As discussões apresentadas, acerca da estrutura produtiva voltada para o mercado internacional, mostram que a infraestrutura e os serviços de transportes são utilizados na viabilização do escoamento de produtos, dentre os quais a soja e seus derivados. Porém, os gargalos logísticos criam dificuldades para o setor exportador de commodities agrícolas, principalmente com a elevação dos custos operacionais, denominados de "custo Brasil", dentre os quais se destacam a malha viária não pavimentada nas conexões com as fazendas, a má conservação das rodovias pavimentadas, o sucateamento da infraestrutura e da malha ferroviária, a precariedade da malha hidroviária, as deficiências nas infraestruturas portuárias, os entraves burocráticos institucionais no sistema aduaneiro, as dificuldades na operacionalização do transporte intermodal e as limitações da infraestrutura de armazenagem (CAIXETA FILHO, 2001; CASTILLO, 2005; PEREIRA, 2010; MONIÉ, 2011; SILVEIRA, 2011).

As possíveis saídas para a superação desses gargalos logísticos estariam relacionadas com o planejamento e com o levantamento de recursos financeiros, do poder público e da iniciativa privada, para o custeio dos investimentos a serem realizados nas melhorias da infraestrutura logística, garantindo assim, mais competitividade ainda do agronegócio, inclusive do setor de soja, nos mercados globais. Na próxima seção, foi abordada a organização espacial da produção de soja e seus derivados, bem como a interconexão com os mercados internacionais por meio da logística de transportes nacional e mundial. 
Mapa 02 - Localização geográfica de armazéns e de silos grãos no território brasileiro

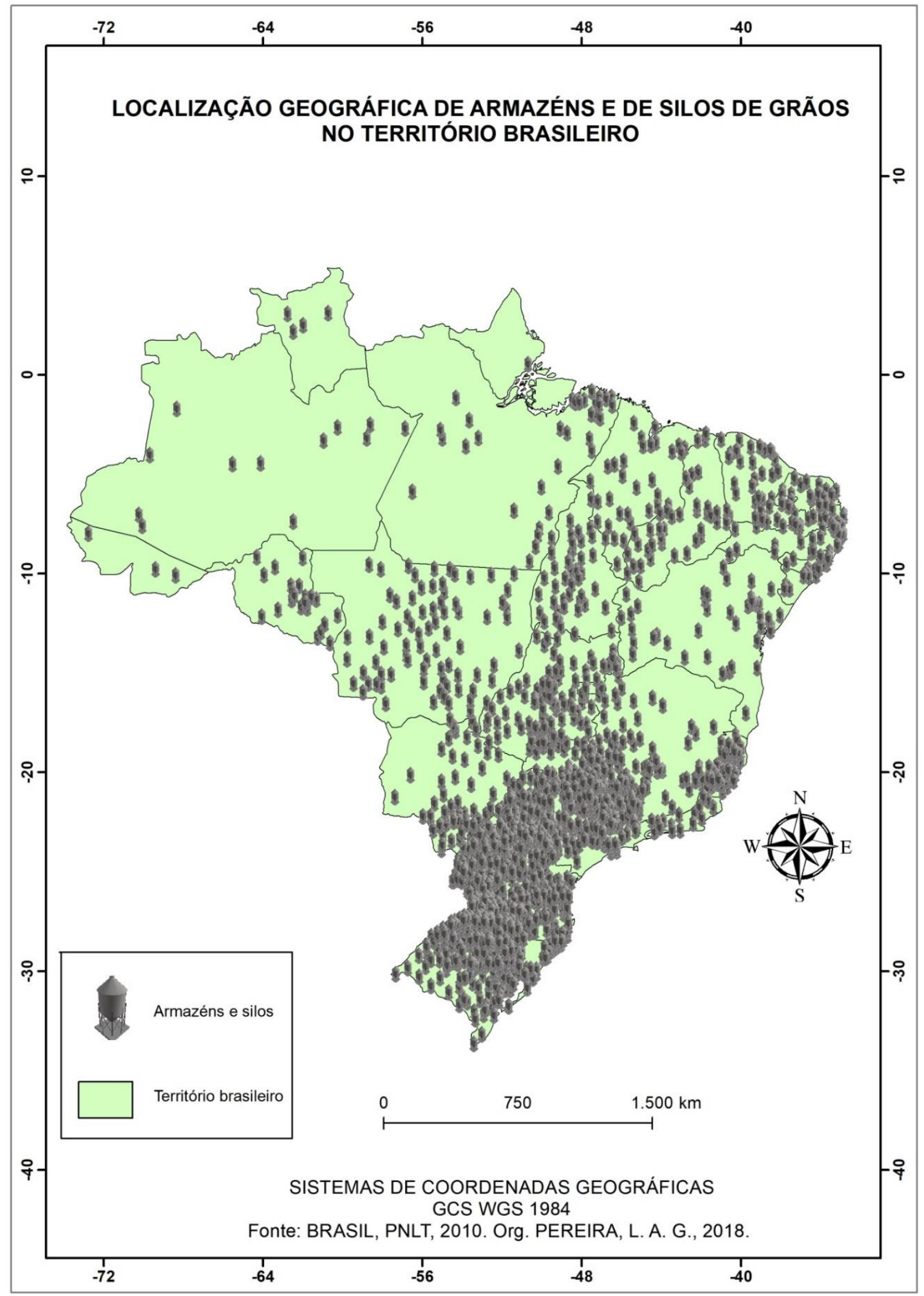

Fonte: BRASIL, Plano Nacional de Logística e Transportes - PNLT, 2010. Org. PEREIRA, L. A. G., 2018 


\subsection{Dinâmica espacial da produção, das exportações e da logística de} transportes sojicultura

A expansão e a manutenção da infraestrutura econômica de transportes e de armazenagem são primordiais para o dinamismo socioeconômico das áreas agrícolas, que produzem a soja e seus derivados, seja nas regiões produtivas tradicionais, como no Sul e Sudeste, e/ou as regiões de expansão denominadas de novas fronteiras agrícolas do Centro-Oeste, do Norte e Nordeste do Brasil (CASTILLO, 2005; CÂMARA, 2015). No contexto da evolução dos mercados de commodities agrícolas, Castillo (2005) trabalhou com dois momentos históricos da produção de soja no território brasileiro: $1^{\circ}$ ) Abrangência temporal do período entre as décadas de 1960 e 1970, apresentando expressividade no aumento da produção de soja, devido a uma política de formação dos complexos agroindustriais nos Estados do Rio Grande do Sul e Paraná, incentivadas por ações estatais, através de subsídios vinculados a incentivos fiscais e financeiros, bem como a ocupação de novas áreas agrícolas. $2^{\circ}$ ) A escala temporal abrangeu 0 período posterior a década de 1980, caracterizada pela consolidação da sojicultura na expansão de novas fronteiras agrícolas em áreas de cerrados. Nesse processo, o Estado continuou com a política de subsídios fiscais e financeiros, favorecendo a ocupação de novas fronteiras agrícolas, principalmente pelos gaúchos, paranaenses e paulistas. Entretanto a crise fiscal dos anos de 1980 levou à revisão e/ou mudança nas formas de incentivos por parte do Estado no segmento agrícola brasileiro.

A saída para a crise econômica nos discursos de grande parte dos políticos e dos agentes econômicos seria a implementação da abertura econômica por meio de ações neoliberais, nas quais são ampliadas a participação da iniciativa privada nas atividades econômicas pelas privatizações e pelas concessões viabilizadas pelo 
Estado. Medeiros (2014), informa que na década de 1990, a crise financeira teve várias repercussões no setor agrícola, tais como a escassez de crédito para financiamentos, aumento e prorrogação de dívidas, elevação das taxas de juros e corrida por linhas de crédito. Neste contexto, tem-se uma ampliação da participação de grupos estrangeiros, principalmente as tradings companies, que compram empresas brasileiras e adquirem recursos no sistema financeiro para fornecer linhas de crédito para financiar os produtores de matérias-primas.

A internacionalização do agronegócio brasileiro intensificou-se naqueles setores voltados para as exportações, abrindo mais espaço, principalmente para os grandes grupos empresariais estrangeiros. Essas corporações não atuam diretamente na produção de soja, entretanto, elas têm uma rede de fornecedores de matéria-prima e também organizam em rede a sua cadeia produtiva no fornecimento de insumos, de sementes selecionadas, de créditos, de processamento, de comercialização, de armazenagem e de transporte dos produtos exportados. Além disso, no segmento agroindustrial existe em menor proporção a participação de empresas brasileiras e de cooperativas (CASTILLO, 2005; MEDEIROS, 2014). É importante destacar que a soja e seus derivados apresentaram um crescimento significativo a partir da década de 1960 no território brasileiro.

Na análise histórica da distribuição espacial da estrutura produtiva da soja em grãos nos municípios brasileiros é notória, na década de 1970, uma concentração nas municipalidades da região Sul, com início de expansão no sentido das denominadas áreas de novas fronteiras agrícolas. Nas décadas posteriores - 1980, 1990, 2000 e 2010 - a produção de soja cresceu nos municípios da região Centro-Oeste, bem como em áreas das regiões Sudeste, Nordeste e Norte, uma vez que receberam investimentos em infraestrutura, linhas de créditos e incentivos fiscais (Vide Mapa 03). 
22 | Geografia do comércio de commodities, dinâmicas espaciais da logística de transportes e dos fluxos de exportações do setor de soja no Brasil

Mapa 03 - Brasil: distribuição e produção de soja por municípios (toneladas)

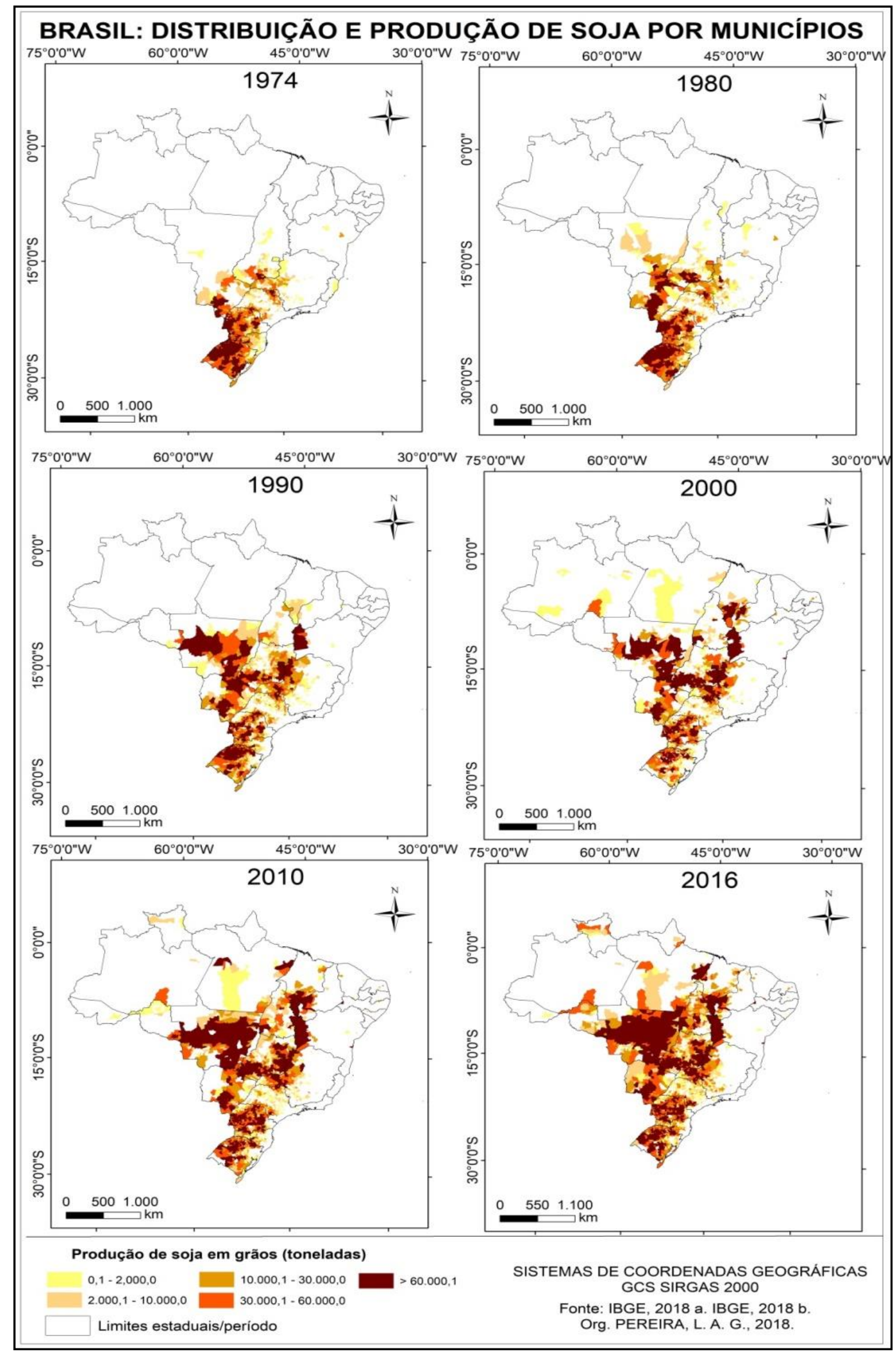

Fonte: IBGE, 2018 a. IBGE, 2018 b. Org. PEREIRA, L. A. G., 2018 
O crescimento da produção de soja no Brasil concentrou-se especialmente nas novas áreas de fronteiras agrícolas da região Centro-Oeste, e também nas áreas tradicionais da região Sul, uma vez que estas receberam incentivos públicos e privados, que atraíram os empresários rurais e as empresas processadoras de produtos agroalimentares estrangeiras e brasileiras, com foco no mercado nacional e internacional. Neste contexto, o Gráfico 01 mostra o crescimento contínuo da produção total de soja em grão no Brasil, em termos proporcionais, em 1965, a exportação de soja representava 14,4\%, crescendo para 33,7\% em 1975, caindo para 10,2\% em 1980, voltando a crescer para 20,5\% em 1990, reduzindo para 13,6\% em 1995. E em 2000 e 2005, o crescimento foi contínuo, atingindo 35, 1\% e 43,8\%, respectivamente, enquanto em 2010 apresentou uma leve queda para 42,3\% e em 2016 atingiu 53,6\%, que foi o melhor resultado em todo o período analisado.

Gráfico 01 - Produção de soja em grão no Brasil: quantidade destinada ao mercado interno e ao mercado externo, no período de 1965 a 2016 (toneladas - 1.000)

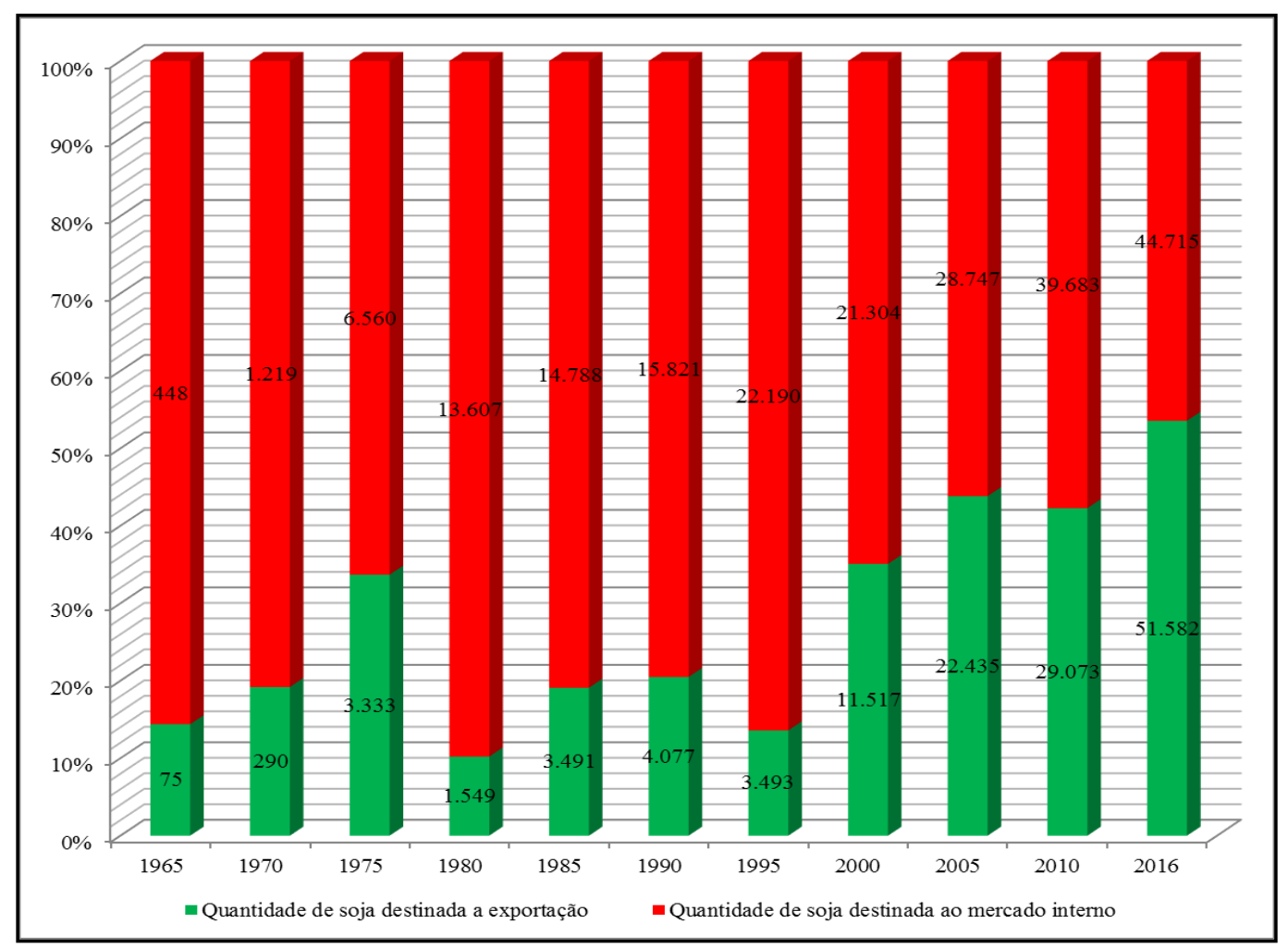

Fonte: FAO, 2017; ITC/Trade Map, 2017. Org. PEREIRA, L. A. G., 2018

Na cadeia produtiva da soja em grão, a parte da produção estava voltada para o mercado interno, sendo utilizada pelas indústrias de processamento na 
fabricação, principalmente de farelos de soja e de óleo de soja, para atender as demandas do mercado brasileiro e também dos mercados globais. Na política de exportações brasileiras de derivados de soja, em 1965/1966, o farelo de soja representava 76,1\% das exportações, subindo para 83,2\% em 1970/1971, nos anos seguintes apresentou queda contínua, chegando a 47,3\% em 2015/2016, o pior desempenho no período estudado. Enquanto em 1965/1966, o óleo de soja não era exportado; em 1970/1971, a venda de óleo de soja para o exterior representava 2,3\%; crescendo para 46,9\% em 1980/1981, regredindo para 16,7\% em 1990/1991, retoma o crescimento novamente, atingindo 41,9\% em 2005/2006. Posteriormente voltou a ter queda, chegando a 16,3\% em 2015/2016. Essas informações podem ser vistas no Gráfico 02.

Gráfico 02 - Estrutura produtiva de farelo de soja e de óleo de soja no Brasil: consumo no mercado interno e exportações (toneladas métricas - 1.000)

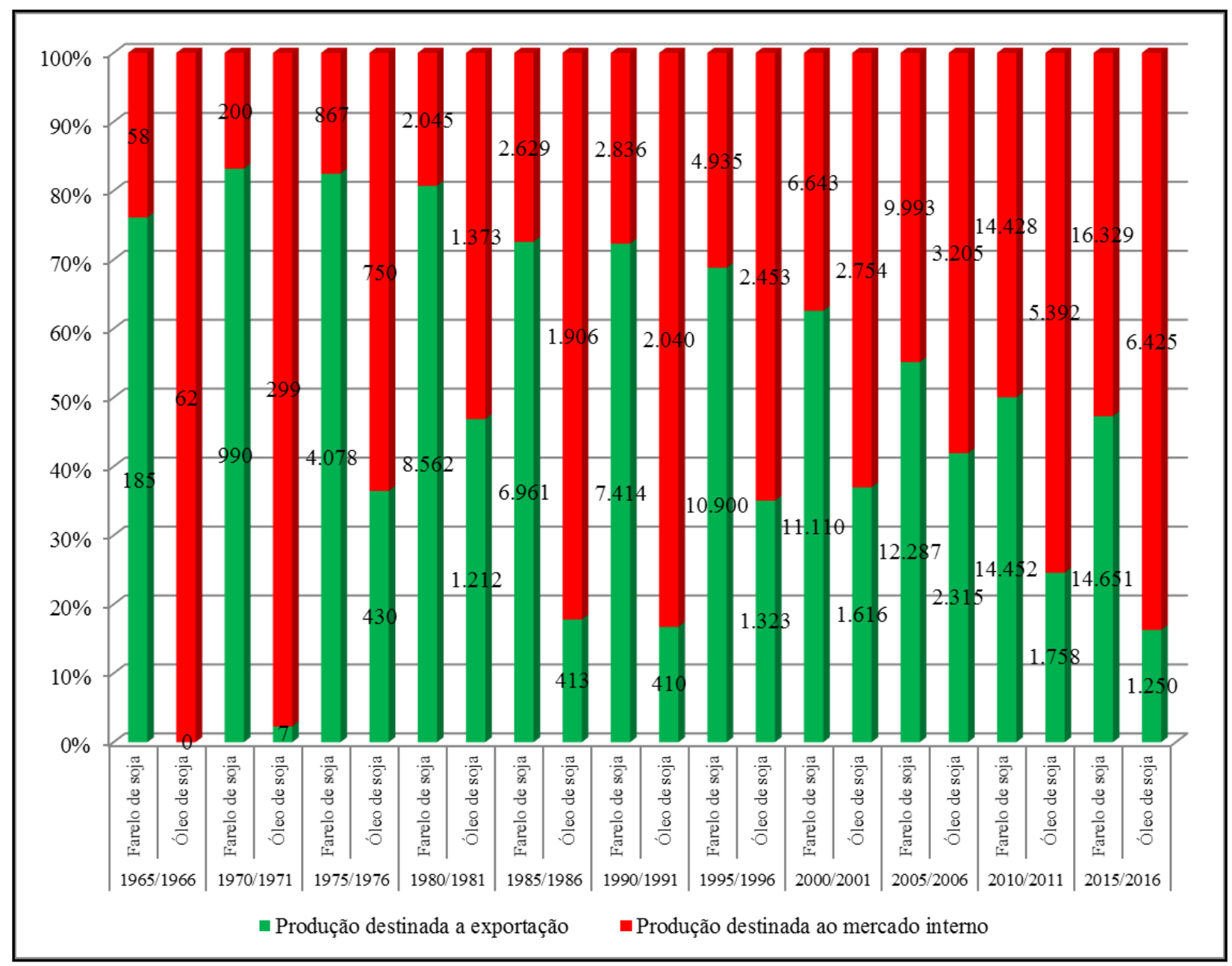

Fonte: United States Department of Agriculture - USDA/Foreign Agricultural Service, 2018. Org. PEREIRA, L. A. G., 2018 
Na interpretação dos gráficos, percebe-se uma ascensão nas exportações de soja, farelo de soja e óleo de soja até por volta de 1975/1976; sendo que entre os anos de 1980 a 1995, a exportação de soja apresentou quedas; depois dos anos 2000 a soja em grãos ampliou a sua participação nas exportações, enquanto o farelo de soja e o óleo de soja reduziu sua participação na política de exportações. Depois dos anos 2000, o Brasil expandiu a exportação de produtos in natura e reduziu a exportação de produtos processados, em um período de boom global das commodities agrícolas e diminuição da participação da indústria na pauta de exportação do Brasil.

O expansionismo do setor de soja, em grão ou processada, na política de exportação territorial, está associado à dinâmica de empresas nacionais e multinacionais que atuam no setor agroindustrial/agrocomercial. Na concepção de Fajardo (2011), o processo de modernização da agricultura, nos moldes da "Revolução Verde", implementado a partir dos anos de 1960, fez com que as empresas agroindustriais estrangeiras ampliassem as suas atividades no território brasileiro, por meio das articulações intersetoriais entre a agricultura e a indústria, que foram estimuladas pelas ações estatais através de incentivos fiscais e financeiros. Tendo como referência as empresas estrangeiras, as empresas nacionais tiveram que adaptar as suas estruturas produtivas aos padrões internacionais agrícolas para serem fornecedoras de insumos ou para concorrerem com elas nos mercados.

As corporações estrangeiras do agronegócio, por meio de suas filiais no Brasil, controlam as exportações de commodities agrícolas pelas estruturas produtivas verticalizadas e horizontalizadas, incluindo também os serviços financeiros, de armazenagem, de comércio e de distribuição para os compradores localizados nos espaços nacionais e internacionais (FAJARDO, 2011; MEDEIROS, 2014). Na política de exportações brasileiras do setor de soja, destaca-se que existe um predomínio das tradings companies estrangeiras e também em proporção 
26 | Geografia do comércio de commodities, dinâmicas espaciais da logística de transportes e dos fluxos de exportações do setor de soja no Brasil

menor tem-se se a participação das cooperativas e das tradings nacionais do agronegócio.

Mapa 04 - Localização geográfica das principais empresas exportadoras do setor do agronegócio: companhias estrangeiras e brasileiras

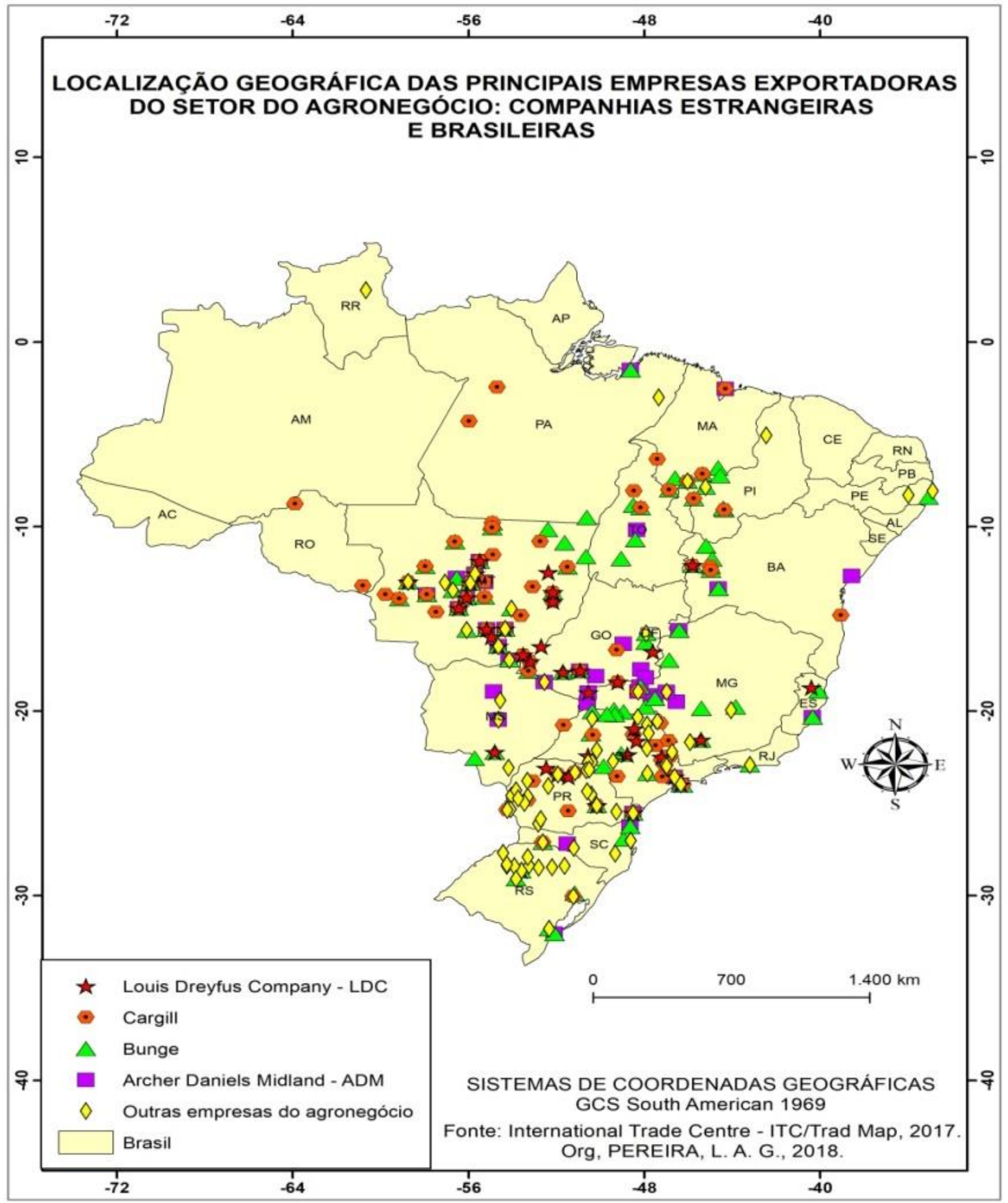

Fonte: International Trade Centre - ITC/Trad Map, 2017.

Org. PEREIRA, L. A. G., 2018 
As principais trading companies estrangeiras que concentram as atividades de comercialização de soja e derivados, para atender as demandas do mercado externo e interno são a Archer Daniels Midland (ADM), a Bunge, a Cargill e a Louis Dreyfus Company (LDC). Além delas, existem também as empresas brasileiras cooperativas e tradings - que são a Amaggi, a C. Vale - Cooperativa Agroindustrial e a COAMO Agroindustrial Cooperativa, dentre outras. O mapa 04 mostra a localização geográfica por domicílio fiscal no território brasileiro, das principais empresas do setor do agronegócio, que exportam a soja e os seus derivados para os mercados globais.

No período de 1997 a 2016, as empresas, localizadas no território brasileiro, tiveram os seus produtos - soja e derivados - comercializados nos mercados internacionais, agrupados conforme as seguintes proporções, o produto "soja, mesmo triturada" representou $65,7 \%$ dos fluxos financeiros e $64,3 \%$ da quantidade em quilograma. Enquanto que o produto denominado de "tortas de soja" [farelo de soja] apresentou 25,8\% dos valores em dinheiro e 31,3\% da quantidade em peso. Já o produto "óleo de soja" representou 8,3\% dos valores financeiros e 4,4\% da quantidade em quilogramas. Os demais produtos representaram valores iguais ou menores a 0,1\% dos valores financeiros e em quilos. Essas informações podem ser observadas na Tabela 01.

Tabela 01 - Exportações do setor de soja e derivados: produtos separados, acumulado no período de 1997 a 2016 (US\$, KG - 1.000.000 e percentual)

\begin{tabular}{c|c|c|c|c|c}
\hline $\begin{array}{c}\text { SH4 ou } \\
\text { NCM }\end{array}$ & Produtos & US\$ & $\%$ & $k g$ & $\%$ \\
\hline 1201 & Soja, mesmo triturada & $195.179,3$ & 65,7 & $522.403,8$ & 64,3 \\
\hline 2304 & Tortas de soja (Farelo de soja) & $76.733,7$ & 25,8 & $254.543,0$ & 31,3 \\
\hline 1507 & Óleo de soja & $24.595,2$ & 8,3 & $35.729,2$ & 4,4 \\
\hline 35040020 & Proteínas de soja & 377,9 & 0,1 & 155,6 & 0,0 \\
\hline 21031010 & Molho de soja & 5,3 & 0,0 & 3,1 & 0,0 \\
\hline 21031090 & Outros molhos de soja & 4,0 & 0,0 & 4,3 & 0,0 \\
\hline 12081000 & Farinha de soja & 4,9 & 0,0 & 8,4 & 0,0 \\
\hline 23099050 & $\begin{array}{c}\text { Preparações com teor cloridrato de } \\
\text { ractopamina = } 2 \% \text { de farelo de } \\
\text { soja }\end{array}$ & 0,8 & 0,0 & 0,3 & 0,0 \\
\hline & Total & $296.901,1$ & 100 & $812.847,7$ & 100 \\
\hline
\end{tabular}

Fonte: MDIC/Aliceweb2, 1997; 1998; 1999; 2000; 2001; 2002; 2003; 2004; 2005; 2006; 2007; 2008; 2009; 2010; 2011; 2012; 2013; 2014; 2015; 2016. Org. PEREIRA, L. A. G., 2018 
Os produtos soja em grãos, farelo de soja e óleo de soja são responsáveis pela quase totalidade das exportações, com destaque para a soja in natura que representou quase dois terços dos produtos exportados. No escoamento destas mercadorias para os mercados globais, a rede logística de transportes se estrutura em transportes nacionais, recintos alfandegados (brasileiros) e transportes internacionais. Os recintos alfandegados - portuários, aeroportuários e pontos de fronteiras - são os locais que interconectam os fluxos das exportações e das importações nas transações comerciais internacionais, sendo eles primordiais no desenvolvimento das atividades socioeconômicas e na dinâmica da prestação de serviços, inclusive dos serviços logísticos e de transportes. A estrutura espacial dos fluxos das exportações se articula em três etapas, na primeira etapa, as rotas que conectam as unidades produtivas (locais de armazenagem) aos recintos alfandegados. Na segunda etapa, os recintos alfandegados recebem os produtos que são desembaraçados e embarcados na matriz de transporte internacional. Na terceira etapa, a partir do recinto alfandegado nacional, a modalidade de transporte internacional, interliga aos recintos alfandegados localizados no exterior, ou seja, nos países importadores (PEREIRA, 2015).

Na primeira etapa, calculando uma média no período de 2010 a 2016, o transporte de soja pelas rotas que vão das fazendas e/ou locais de armazenagens até os recintos alfandegados brasileiros, ocorreu da seguinte forma: cerca de 21,9 milhões de toneladas circularam pelo transporte ferroviário, o que equivale a 47,6 \% da circulação, enquanto aproximadamente 19,6 milhões de toneladas locomoveram-se pelo transporte rodoviário, correspondendo a 42,5\% da movimentação, e cerca 4,6 de toneladas foram transportadas pelas hidrovias, representando 9,9\% dos fluxos. Essas informações são mostradas no Gráfico 03. Quando a soja chega aos recintos alfandegados, pela malha ferroviária e pela 
malha hidroviária, geralmente é utilizado também o transporte intermodal emprego de dois ou mais meios de transportes na circulação do produto - pois no início do processo do fluxo faz-se uso do transporte rodoviário para interconexão do transporte ferroviário e hidroviário, sendo que eles não chegam diretamente a todas as unidades produtivas, armazenadoras e/ou processadoras.

Na segunda etapa, os produtos do setor de soja e derivados foram direcionados aos recintos alfandegados portuários, aeroportuários e pontos de fronteiras, uma vez que espacialmente o porto de Paranaguá (PR) recebeu 27,5\% dos fluxos financeiros e $28,5 \%$ da quantidade em quilogramas. Na sequência, o porto de Santos (SP) concentrou $24,7 \%$ dos fluxos financeiros e $24,9 \%$ da quantidade em quilos/volume. O porto de Rio Grande (RS) realizou o escoamento de $17,2 \%$ dos fluxos em dinheiro e de $16,5 \%$ do peso/volume. Os recintos portuários de Vitória (ES) e de São Francisco do Sul (SC) movimentaram valores financeiros que variam entre $7,3 \%$ e 7,6\%, e a quantidade em peso/volume entre $7,5 \%$ e $7,6 \%$ dos fluxos. Nos terminais portuários de Salvador, de São Luís, de Santarém e de Manaus circularam entre 1,6\% e 4,8\% dos valores em dinheiro e $1,5 \%$ e $4,5 \%$ da quantidade em volumes/quilogramas. Nos demais recintos alfandegados (portuários, aeroportuários e pontos de fronteiras) foram embarcados produtos com valores em dinheiro e quantidades em quilos iguais e/ou inferiores a 1,0\%. O Mapa 05 mostra a distribuição dos fluxos de soja e derivados exportados pelos recintos alfandegados, acumulados entre os anos de 1997 a 2016, em valores financeiros e quantidades em quilogramas.

Os meios de transportes nacionais e internacionais assumem o papel de interligar física e territorialmente os mercados globais. Desta forma, ao sair dos recintos alfandegados brasileiros, as exportações de soja e seus derivados seguem para os mercados organizados em blocos econômicos, que concentram os 
importadores. Na organização espacial dos fluxos, a Cooperação Econômica ÁsiaPacífico - APEC (Excluso o NAFTA) recebeu 54,7\% dos fluxos das mercadorias em dinheiro e 49,3\% quantidade em peso/volume. Em seguida, os agentes econômicos da União Europeia importaram 34,8\% dos valores em dinheiro e 41,6\% da quantidade volume/quilograma. Todos os demais blocos e/ou países (Tratado Norte-Americano de Livre Comércio - NAFTA; Mercado Comum do Sul - MERCOSUL 5; Associação Sul-Asiática para a Cooperação Regional - SAARC e União Aduaneira da África Austral - SACU) importaram valores financeiros e quantidades quilogramas menores que 10\%. Essas informações podem observadas no Mapa 06.

Gráfico 03 - Movimentação de soja por meios de transportes no Brasil: rota entre as unidades produtoras e os recintos alfandegados (percentual e milhares de toneladas)

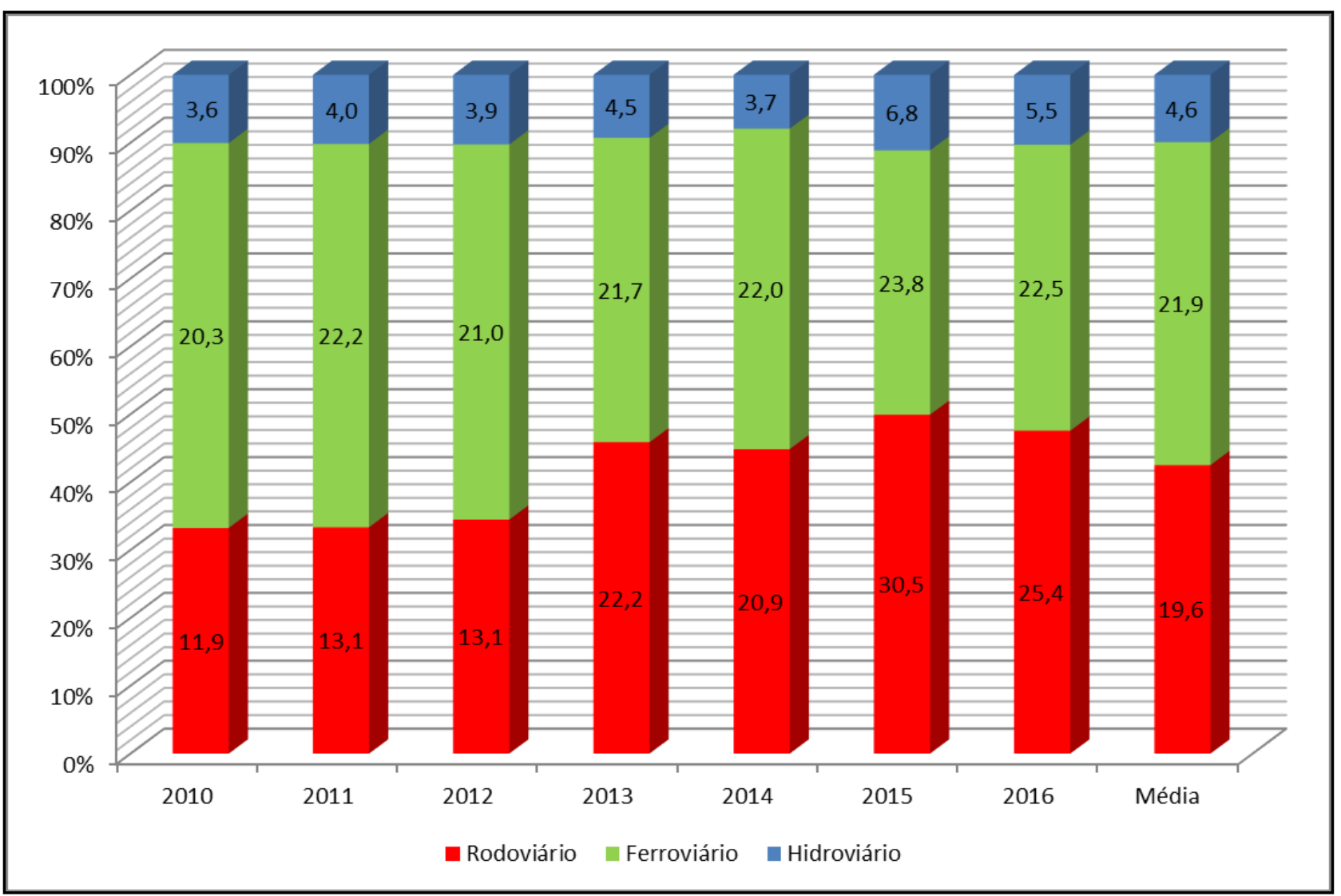

Fonte: Ministério dos Transportes, Portos e Aviação Civil - MTPA, 2017b Org. PEREIRA, L. A. G., 2018 
Mapa 05 - Exportações do setor de soja no Brasil: fluxos por recintos alfandegados, no período de 1997 a 2016 (US\$/FOB e quilo - 1.000.000)

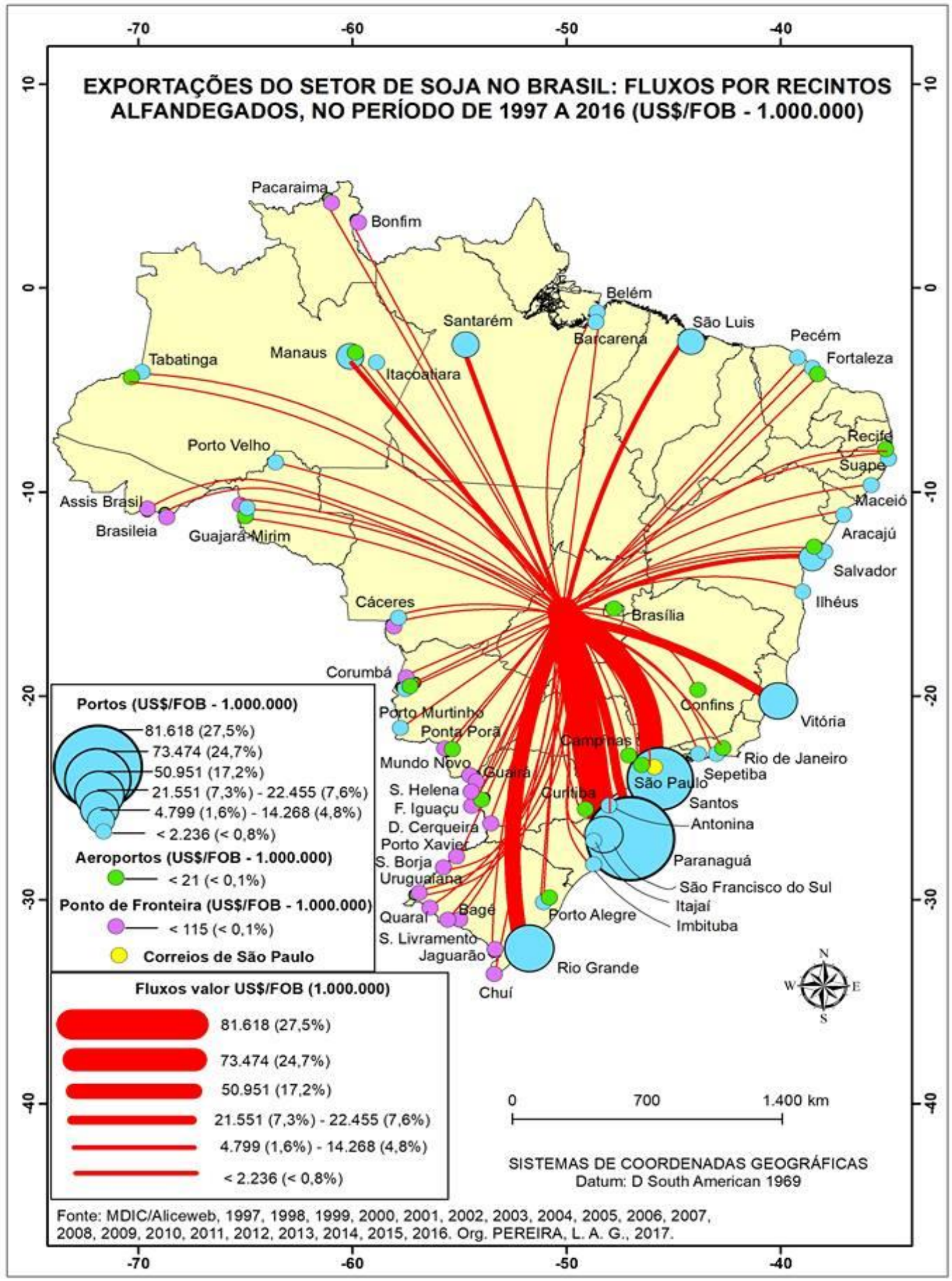




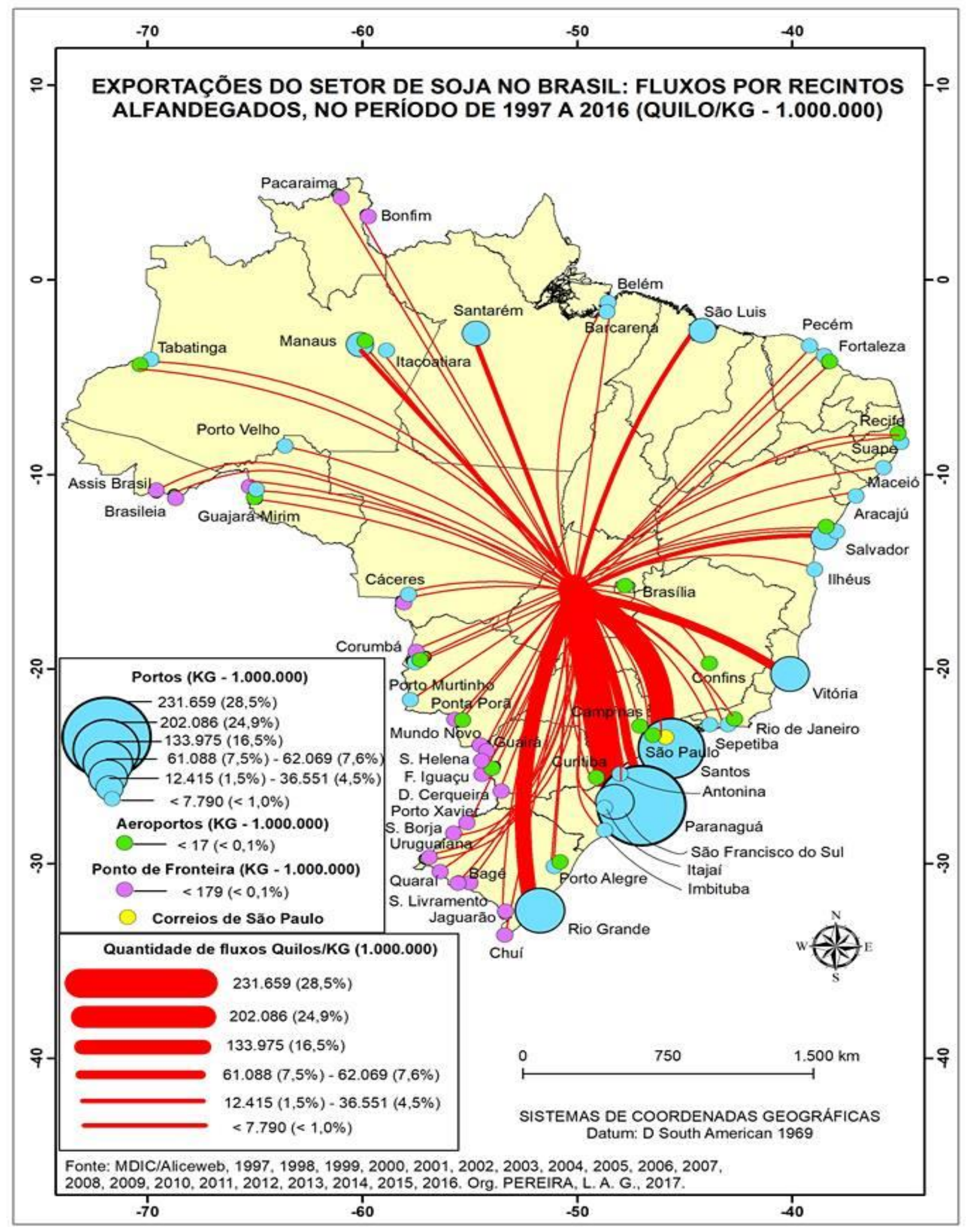

Fonte: MDIC/Aliceweb2, 1997; 1998; 1999; 2000; 2001; 2002; 2003; 2004; 2005; 2006; 2007; 2008; 2009; 2010; 2011; 2012; 2013; 2014; 2015; 2016

Org. PEREIRA, L. A. G., 2011 
Mapa 06 - Organização das exportações brasileiras do setor de soja e derivados por blocos econômicos, acumulado no período de 1997 a 2016 (US\$/FOB e QUILO/KG 1.000.000)
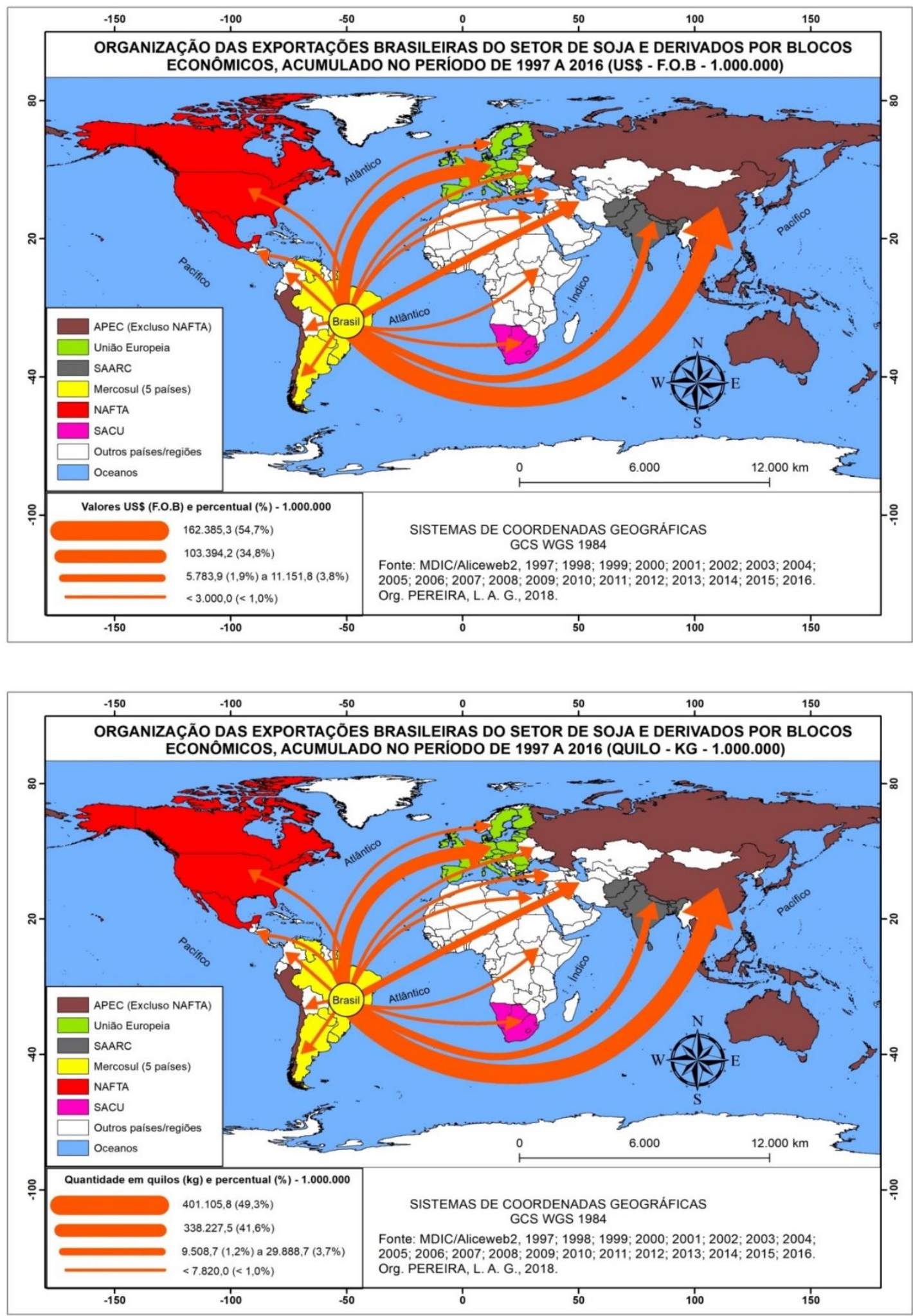

Fonte: MDIC/Aliceweb2, 1997; 1998; 1999; 2000; 2001; 2002; 2003; 2004; 2005; 2006; 2007; 2008; 2009; 2010; 2011; 2012; 2013; 2014; 2015; 2016. Org. PEREIRA, L. A. G., 2018 
$\mathrm{Na}$ dinâmica espacial, os produtos exportados chegaram aos recintos alfandegados por meio do transporte ferroviário, rodoviário e hidroviário. De modo que três recintos alfandegados [Paranaguá, Santos e Rio Grande] concentraram $69,4 \%$ dos fluxos financeiros e $69,9 \%$ da quantidade em quilos. A centralização dos fluxos nos recintos supracitados ocorreu por causa da localização das unidades processadoras, da disponibilidade de locais de armazenagem, da oferta de serviços logísticos voltados para o segmento agroindustrial e da infraestrutura propiciar as conexões entre as regiões produtoras e os recintos alfandegados de Paranaguá, Santos e Rio Grande. Além dessas áreas, no século XXI é visível a expansão, ainda incipiente, na utilização da infraestrutura de transportes e dos recintos alfandegados no "Arco Norte".

Os agentes econômicos, que compraram os produtos do setor de soja e seus derivados originários do Brasil, concentraram-se, em sua grande maioria, nos mercados da APEC e da União Europeia. Estes produtos são utilizados em setores estratégicos da economia, dos quais destacam-se a alimentação da população, a alimentação de animais e a geração de bioenergia para atender demandas das atividades agroalimentares, industriais e dos sistemas financeiros especulativos. Existem diversidades na composição de elementos territoriais e socioeconômicos, que podem ser visualizados nas redes de produção, de exportações e de escoamento de soja e seus derivados em uma dimensão espacial que incorpora os links de serviços logísticos de transportes entre os territórios brasileiros e os mercados internacionais.

\section{CONSIDERAÇÕES FINAIS}

A Geografia do Comércio de commodities agrícolas apresentou as dimensões socioeconomicas e espaciais na composição do setor agroindustrial, especificamente o setor de soja e seus derivados, que se incorpora no complexo sistema de comércio global, no qual ocorrem as transações comerciais, em um 
ambiente de muita competitividade que atende as demandas dos nichos de mercados e de uma cadeia produtiva territorialmente fragmentada. Na estrutura socioespacial, a logística de transportes, por meio da infraestrutura e dos serviços, assumiu o papel de interconectar fisicamente os mercados globais, integrando e interagindo de forma constante com os fluxos virtuais de capitais e de informações.

Na dinâmica das interações espaciais de circulação de soja e derivados, as grandes corporações do agronegócio, destacando-se as multinacionais, que associadas ao sistema financeiro passaram a controlar os geonegócios, através das redes de fornecedores, de produção, de logística de transportes, de gerenciamento de riscos e de distribuição nos diversos mercados internacionais. Na política comercial brasileira, o setor de agronegócio é estratégico na composição de resultados positivos da balança comercial, na medida em que sua expansão ocorreu em um contexto de modernização da agricultura e de implantação de indústrias processadoras, onde os investimentos públicos e privados foram imprescindíveis.

As estruturas produtivas e as políticas de comercialização de produtos agroalimentares e agroenergéticos são controladas e centralizadas por empresas, denominadas de trading companies, nomeadamente as multinacionais Cargill, ADM, Bunge e Louis Dreyfus. Além destas, existem outras empresas estrangeiras e também, em menor proporção, empresas brasileiras, que participaram das exportações do setor de soja e derivados. Nesta dinâmica socioeconômica, os principais produtos exportados são a soja em grãos, o farelo de soja e o óleo de soja, que demandam serviços logísticos de transportes para chegarem aos mercados internacionais.

A organização espacial dos fluxos de soja e seus derivados dos locais de produção (fazendas e armazéns) até os recintos alfandegados ocorreu em maiores proporções por meio do modal de transporte rodoviário e ferroviário, e em menor proporção foi utilizado o transporte hidroviário. Os recintos alfandegados 
portuários, aeroportuários e pontos de fronteiras receberam os fluxos de soja e derivados, que foram desembaraçados (liberação de documentação) e embarcados nas matrizes de transportes internacionais, com destino aos mercados globais. Neste processo de escoamento das mercadorias (soja e derivados), o transporte marítimo concentrou cerca de 99,7\% dos fluxos financeiros e da quantidade em peso/volume, por ser o meio de transporte que apresenta o menor custo para os produtos de baixo valor agregado do setor de commodities agrícolas nas conexões com os mercados internacionais.

A distribuição dos fluxos de soja e derivados concentrou-se nos três principais portos brasileiros, utilizados no escoamento de commodities agrícolas, que são: Paranaguá, Santos e Rio Grande, respectivamente. Destes portos, dois estão localizados na região Sul (Paranaguá e Rio Grande) e um na região Sudeste (Santos), regiões pioneiras no desenvolvimento do plantio de soja, na instalação de empresas processadoras e na implantação de sistemas de armazenagem, que expandiram os serviços logísticos, especializados na interconexão dos mercados internacionais, inclusive atraindo grande parte dos fluxos de produtos agrícolas e seus derivados da região Centro-Oeste do Brasil. Além disso, é visível um crescimento dos fluxos de soja e seus derivados nos portos das regiões Norte e Nordeste, muito em função da criação de novas rotas logísticas, rodovias, ferrovia e terminais portuários, que também atendem a produção dessas áreas agrícolas.

As commodities agrícolas são importantes no atendimento às demandas dos setores agroalimentares humanos, de alimentação de animais e de geração da agroenergia. Desta forma, o agronegócio do setor de soja e derivados atendeu demandas dos mercados da APEC e da União Europeia, que receberam cerca de $89,5 \%$ dos fluxos em dinheiro e $90,9 \%$ da quantidade em peso/volume. Para os demais mercados juntos, foram direcionados aproximadamente $10,5 \%$ dos fluxos financeiros e $9,1 \%$ da quantidade em quilos. O desafio que se coloca na agenda dos agentes públicos e privados no atendimento destes mercados é a garantia de investimentos que propiciem melhorias na infraestrutura logística de transportes, 
visando à otimização dos fluxos e a redução dos custos logísticos no processo de movimentação de produtos agroalimentares.

\section{REFERÊNCIAS}

BADER, K.L.The Soybean Marketing Systems. Journal of the American Oil Chemists' Society, [S.I], v. 58, n.3, p. 151-153, 1981. Disponível em: https://link.springer.com/article/10.1007/BF02582325. Acesso em: 10 mar. 2018.

BALLOU, R.H. Logística empresarial: transportes, administração de materiais e distribuição física. Tradução de Hugo T. Y. Yoshizaki. São Paulo: Atlas, 1993. 388 p.

BALLOU, R. H. Gerenciamento da cadeia de suprimentos/logística empresarial. 5. ed. Tradução de Raul Rubenich. Porto Alegre: Bookman, 2006. 616 p.

BINI, D.A.; CANEVER, M.D.; DENARDIM, A.A. Correlação e causalidade entre os preços de commodities e energia. Nova Economia, Belo Horizonte, v. 25, n. 1, p. 143-160, 2015.Disponível em: http://www.scielo.br/scielo.php?script=sci_arttext\&pid=S010363512015000100143. Acesso em: 5 out./ 2017.

BRASIL. Plano Nacional de Logística e transportes - PNLT. Bases geográficas. Brasília: Ministério dos Transportes, $2010 . \quad$ Disponível em: http://www.transportes.gov.br/bit.html. Acesso em: 22 fev. 2015.

CAIXETA-FILHO, J. V. Logística para a agricultura brasileira. Revista Brasileira de Comércio Exterior, [S.I.], v. 103, p. 18-30, 2010. Disponível em: http://www.funcex.org.br/publicacoes/rbce/material/rbce/103_JVCF.pdf. Acesso em: 10 set. 2017.

CAIXETA-FILHO, J. V. Introdução: a competitividade do transporte no agribusiness brasileiro. In CAIXEITA-FILHO, J. V.; GAMEIRO, A. G. Transporte e logística em sistemas agroindustriais. São Paulo: Atlas, 2001. 218 p. p. 11-20.

CÂMARA, G. M. S. Introdução ao agronegócio soja. Piracicaba: ESALQ, 2015. 30 p. Disponível em: http://www.esalq.usp.br/departamentos/lpv/sites/default/files/LPV\%200584\%202015 \%20-\%20Soja\%20Apostila\%20Agronegocio.pdf. Acesso em: 6 maio 2017.

CASTILLO, R. Exportar alimentos é a saída para o Brasil?: O caso do complexo da soja. In ALBUQUERQUE, E. S. (Org.). Que país é esse? Pensando o Brasil contemporâneo. São Paulo: Globo, 2005. 372 p.p.283-307.

DAVID, P.; STEWART, R. Logística internacional. Tradução de Laís Andrade. São Paulo: Cengage Learning, 2010. 416 p.

FAJARDO, S. A ação territorial corporativa no espaço rural. In VIDEIRA, S. L.; COSTA, P. A.; FAJARDO, S. (Org.). Geografia Econômica: (re)leituras contemporâneas. Rio de Janeiro: Letra Capital, 2011. 193 p. p. 47-66. 
FOOD AND AGRICULTURE ORGANIZATION OF THE UNITED NATIONS - FAO. Faostat: production. 2017. Disponível em: http://www.fao.org/faostat/en/\#data. Acesso em: 22 fev. 2018.

FREDERICO, S. Desvendando o agronegócio: financiamento agrícola e o papel estratégico do sistema de armazenamento de grãos. GEOUSP: Espaço e Tempo, [S.I.], n. 27, p. 47-62, 2010. Disponível em: http://www.revistas.usp.br/geousp/article/view/74154. Acesso em: 20 out. 2017.

GEMAN, H. Agricultural finance: from crops to land, water and infrastructure. Chichester: John Wiley \& Sons Ltd, 2015. 291 p.

GRANT, R. The Economic Geography of Global Trade. In SHEPPARD, E.; BARNES, T. J. (Ed.). A companion to Economic Geography. Oxford: Blackwell blishers, 2000. 518 p.p. 411-431.

HUGHES, Al. Geographies of exchange and circulation: transnational trade and governance. Progress in Human Geography, v. 30, n. 5, p. 635-643, 2006. Disponível em: http://journals.sagepub.com/doi/abs/10.1177/0309132506070179. Acesso em: 12 maio 2014.

INSTITUTO BRASILEIRO DE GEOGRAFIA E ESTATÍSTICA - IBGE. Divisão territorial Bases cartográficas. Brasília: IBGE, 2018a. Disponível em: https://mapas.ibge.gov.br/bases-e-referenciais.html ftp://geoftp.ibge.gov.br/organizacao_do_territorio/malhas_territoriais/municipios_187 2_1991/divisao_territorial_1872_1991/. Acesso em: 20 mar. 2018.

INSTITUTO BRASILEIRO DE GEOGRAFIA E ESTATÍSTICA - IBGE. Sidra - produção agrícola municipal: Soja em grão. IBGE: Brasília, 2018b. Disponível em: https://sidra.ibge.gov.br/Tabela/1612. Acesso em: 20 mar. 2018.

INTERNATIONAL TRADE CENTRE - ITC/TRADEMAP. Trade statistics for international business development monthy, quarterly and yearly trade data, import \& export values. Genebra: ITC/TRADEMAP, 2017. Disponível em: www.trademap.org. Acesso em: 15 set. 2017.

LIMA, T. O protecionismo agrícola nos Estados Unidos: resiliência e economia política dos complexos agroindustriais. São Paulo: Editora UNESP, 2018. 203 p.

MARTINS, R. S. et al. Decisões estratégicas na logística do agronegócio: compensação de custos transporte-armazenagem para a soja no estado do Paraná. Revista de administração contemporânea, [S.I.], v. 9, v. 1, p. 53-78, 2005. Disponível em:

http://www.scielo.br/scielo.php?script=sci arttext\&pid=S1415-65552005000100004. Acesso em: 15 jul./ 2017.

MCCONNELL, J. E.; ERICKSON, R. A. Geobusiness: An International Perspective for Geographers. Journal of Geography, [S.I.], v. 85, n.3, p. 98-105, 1986. Disponível em: https://www.tandfonline.com/doi/abs/10.1080/00221348608979014. Acesso em: 20 set./2017. 
MEDEIROS, M. C. A Geografia do mercado mundial de produtos agroalimentares e o papel do Brasil. Raega - O Espaço Geográfico em Análise, [S.I.], v. 31, p. 260 - 279, 2014. Disponível em: https://revistas.ufpr.br/raega/article/view/32943. Acesso em: 12 fev. 2018.

MINISTÉRIO DA INDÚSTRIA, COMÉRCIO EXTERIOR E SERVIÇOS - MDIC. ALICEWEB2. Exportações. Brasília: MDIC, 1997, 1998, 1999, 2000, 2001, 2002, 2003, 2004, 2005, 2006, 2007, 2008, 2009, 2010, 2011, 2012, 2013, 2014, 2015, 2016. Disponível em: http://aliceweb2.mdic.gov.br/. Acesso em: 18 abr./ 2017.

MINISTÉRIO DOS TRANSPORTES, PORTOS E AVIAÇÃO CIVIL - MTPA. Corredores logísticos estratégicos: complexo de soja e milho. Brasília: MTPA, 2017a. 100 p.

MINISTÉRIO DOS TRANSPORTES, PORTOS E AVIAÇÃO CIVIL - MTPA. Anuário Estatístico de Transportes (2010-2016). Brasília: MTPA, 2017b. 56 p.

MONIÉ, F. Dinâmicas produtivas, logística e desenvolvimento territorial. In COSTA, Pierre; VIDEIRA, S. L.; FAJARDO, S. (Org.). (RE) leituras da Geografia Econômica. Rio de Janeiro: Letra Capital Editora, 2011, 193p. p. 145-167.

NEGUT, S. Rapid Changes of International Trade Flows Geography. An Approach Grounded on the Knowledge-Based Economy Concept. Amfiteatru Economic, v. XIII, n. 30, p.632-645, 2011. Disponível em: https://www.econstor.eu/handle/10419/168739. Acesso em: 12 out. 2015.

NOVAES, A. G. Logística e gerenciamento da cadeia de distribuição: estratégia, operação e avaliação. 5. ed. Rio de Janeiro: Elsevier, 2001. 409 p.

OLIVEIRA, A. U. A Mundialização da Agricultura Brasileira. São Paulo: Iandé, 2016. $545 \mathrm{p}$.

PEREIRA, L. A. G. Planejamento e desenvolvimento: Logística de transportes e exportações na mesorregião norte de Minas Gerais. 2010. 172 f. Dissertação (Mestrado em Desenvolvimento Social) - Programa de Pós-Graduação em Desenvolvimento Social, UNIMONTES, Montes Claros, 2010.

PEREIRA, L. A. G. Logística de transportes e comércio internacional: os fluxos das exportações e das importações de mercadorias no norte de Minas Gerais. 2015. 219 f. Tese (Doutorado em Geografia) - Programa de Pós-Graduação em Geografia, Instituto de Geografia, UFU, Uberlândia, 2015.

PEREIRA, L. A. G.; FERREIRA, W. R. Logística de transportes, comércio internacional e fluxos das exportações no norte de Minas Gerais. Boletim Goiano de Geografia, [S.I.], v. $36, \quad$ n. 1, p. $67 \quad$ - 85, 2016. Disponível em: https://revistas.ufg.br/bgg/article/view/40368. Acesso em: 14 out. 2017.

PONTES, H. L. J.; CARMO, B. B. T.; PORTO. A. J. V. Problemas logísticos na exportação brasileira da soja em grão. Revista Eletrônica Sistemas \& Gestão, [S.I.], v. 4, n. 2, p. 155-181, 2009.

Disponível

em: 
http://www.revistasg.uff.br/index.php/sg/article/view/V4N2A5/V4N2A5. Acesso em: 18 set. 2017.

RODRIGUE, J.; COMTOIS, C.; SLACK, B. The geography of transport systems. 3. ed. London: Routledge, 2013. 146 p.

ROSSI-HANSBERG, E. A Spatial Theory of Trade. The American Economic Review, v. 95, n. 5, p. 1464-1491, 2005. Disponível em: https://www.aeaweb.org/articles?id=10.1257/000282805775014371. Acesso em: 26 out. 2012.

SCOPPOLA, M. Trade Policies and the Strategies of Multinationals in the International Grain Market. Agribusiness, [S.I.], v. 9, n., 3, p. 189-204, 1993. Disponível em: https://onlinelibrary.wiley.com/doi/abs/10.1002/15206297\%28199305\%299\%3A3\%3C 189\%3A\%3AAID-AGR2720090302\%3E3.0.CO\%3B2-7. Acesso em: 18 fev./ 2018.

SILVEIRA, M. R. Geografia da circulação, transportes e logística: construção epistemológica e perspectivas. In SILVEIRA, M. R. (Org.). Circulação, transportes e logística: diferentes perspectivas. São Paulo: Outras Expressões, 2011. 624 p.p.21-68.

TRIGAL, L. L., et al. Diccionario de geografía aplicada y profesional : terminología de análisis, planificación y gestión del território. León: Universidad de León, 2015. 677 p.

United States Department of Agriculture -USDA/Foreign Agricultural Service. Commodities. 20. Acesso em: 10 abr. 2018.

WAQUIL, P. D.; MIELE, M.; SCHULTZ, G. Mercados e comercialização de produtos agrícolas. Porto Alegre: Editora da UFRGS, 2010. Disponível em: http://www.ufrgs.br/cursopgdr/downloadsSerie/derad016.pdf. Acesso em: 22 out./2017. 